\title{
10. UPPER CRETACEOUS TO MIOCENE PLANKTONIC FORAMINIFERAL BIOSTRATIGRAPHY: RESULTS OF LEG 150X, THE NEW JERSEY COASTAL PLAIN DRILLING PROJECT ${ }^{1}$
}

\author{
Chengjie Liu, ${ }^{2}$ James V. Browning, ${ }^{2}$ Kenneth G. Miller, ${ }^{2,3}$ and Richard K. Olsson ${ }^{2}$
}

\begin{abstract}
Planktonic foraminiferal biostratigraphic study of Leg 150X boreholes at Island Beach, Atlantic City, and Cape May provides good biostratigraphic control for Eocene and older strata, limited control on Oligocene strata, and little control on Miocene strata. Upper Cretaceous to Eocene assemblages are open marine faunas, and most of the standard tropical/subtropical planktonic foraminiferal zones are represented in the Leg 150X boreholes. Oligocene planktonic foraminiferal assemblages are low in diversity, many marker taxa are absent, and standard planktonic foraminiferal zonations are difficult to apply. This reflects a shallow depositional paleoenvironment and local/global climatic cooling. Some lower Miocene intervals contain foraminifers, although the shallow depositional environment (inner neritic) excludes most marker taxa. Sediments younger than middle Miocene lack age-diagnostic foraminifers. The presence of most Late Cretaceous to Eocene zones indicates that hiatuses are short in duration. The turning point is during the Eocene/Oligocene transition: since the beginning of the Oligocene, depositional breaks are more frequent and their duration is longer. This may reflect larger, more rapid sea-level changes, consistent with increasing ice volume.
\end{abstract}

\section{INTRODUCTION}

The New Jersey Coastal Plain Drilling Project, Ocean Drilling Program (ODP) Leg 150X, completed three boreholes (Island Beach and Atlantic City in 1993 and Cape May in 1994) that penetrated a total of $4175 \mathrm{ft}(1272.5 \mathrm{~m})$ of sediments and recovered $3166.4 \mathrm{ft}$ (965.1 m) of core (Miller et al., 1994a, 1994b; Miller, et al., 1996; Fig. 1). The oldest sediments recovered were uppermost Cretaceous at Island Beach, upper middle Eocene at Atlantic City, and upper Eocene at Cape May. At Island Beach, drilling penetrated $\sim 35 \mathrm{ft}$ $(10.7 \mathrm{~m})$ of Upper Cretaceous, $108 \mathrm{ft}(32.9 \mathrm{~m})$ of Paleocene, $379 \mathrm{ft}$ $(115.5 \mathrm{~m})$ of Eocene, $225 \mathrm{ft}(68.6 \mathrm{~m})$ of Oligocene, and $\sim 427 \mathrm{ft}(130.2$ $\mathrm{m})$ of Miocene sediments. At Atlantic City, drilling penetrated $271 \mathrm{ft}$ $(82.6 \mathrm{~m})$ of middle and upper Eocene, $273 \mathrm{ft}(83.2 \mathrm{~m})$ of Oligocene, and $768 \mathrm{ft}(234.1 \mathrm{~m})$ of Miocene strata. At Cape May, $140 \mathrm{ft}(42.7 \mathrm{~m})$ of upper Eocene, $180 \mathrm{ft}(54.9 \mathrm{~m})$ of Oligocene, and $823 \mathrm{ft}(250.9 \mathrm{~m})$ of Miocene were penetrated. Pliocene and younger sediments of various thickness were also recovered from the three boreholes.

In general, the Cretaceous to Eocene sections have better biostratigraphic control than younger sediments owing to deposition in predominantly open marine paleoenvironments. Biostratigraphic correlations of Oligocene strata are limited because of the rare occurrence of marker species in shallow marine paleoenvironments, a temperate paleoclimate, more frequent sea-level fluctuations, resulting in hiatus development and poor preservation of microfossils. The Miocene sediments were mostly deposited in shallow marine to prodelta environments. Detailed planktonic foraminiferal biostratigraphic study of the Miocene is not possible due to the absence of planktonic foraminiferal index taxa. Sediments younger than Miocene are basically barren of planktonic foraminifers. Therefore, systematic chronologic study and direct stratigraphic correlation of the Miocene and younger sediments must rely on strontium isotopic, diatom, and dinocyst stratigraphic studies.

${ }^{1}$ Miller, K.G., and Snyder, S.W. (Eds.), 1997. Proc. ODP, Sci. Results, 150X: College Station, TX (Ocean Drilling Program).

Department of Geological Sciences, Rutgers University, Piscataway, NJ 08854, U.S.A. cheliu@ rci.rutgers.edu

${ }^{3}$ Lamont-Doherty Earth Observatory of Columbia University, Palisades, NY 10964, U.S.A.
The objectives of this study are to (1) present detailed planktonic foraminiferal biostratigraphic correlation of the Paleogene sediments for the borehole sections, (2) provide biochronological control of the sedimentary sequences and major hiatuses, (3) study planktonic foraminiferal assemblage successions in a temperate paleoenvironment, and (4) demonstrate the relationship of sea-level events with paleoenvironmental change.

\section{MATERIAL AND METHODS}

Sample sizes used in this study range from 10 to $50 \mathrm{~cm}^{3}$ depending on the abundance of microfossils in the sediment. One 10- and $20-\mathrm{cm}^{3}$ fresh sample was taken from each core $(5-10 \mathrm{ft})$ onsite for preliminary biostratigraphic investigation. After initial examination, additional samples were obtained at the Rutgers Core Laboratory where the cores were temporarily stored. Samples were processed by various micropaleontological techniques according to lithology and concentration of microfossils. Samples were soaked in 3\% hydrogen peroxide for a few hours to overnight to remove organic material followed by washing through a sieve with a $63-\mu \mathrm{m}$ mesh. For some clay-rich samples, boiling in $\sim 3 \%$ sodium carbonate $\left(\mathrm{Na}_{2} \mathrm{CO}_{3}\right)$ solution and then washing in warm tap water through a sieve with $63-\mu \mathrm{m}$ openings proved to be an efficient procedure. After washing, the samples were dried at $\sim 50^{\circ} \mathrm{C}$ in an oven. Less fossiliferous samples (usually Oligocene and Miocene) were floated in tetrachloroethylene to concentrate microfossils. After such treatment, microfossils are concentrated, and most specimens are clean and without obvious damage. Samples were weighed before and after processing to obtain grain size data. The larger size fraction was obtained by separation of $>250-\mu \mathrm{m}$ (medium sand) from 63- to $250-\mu \mathrm{m}$-size (fine sand) fraction using a $250-\mu \mathrm{m}$ sieve. The grain-size data are by-products of micropaleontological study and proved to be useful quantitative estimates of lithology. Because grain size directly reflects porosity and permeability of the formations, it was used in recognizing subsurface geohydrologic units (Miller et al., 1994a, 1994b; Miller, et al., 1996).

Initial biostratigraphic studies were conducted using a binocular stereo light microscope at $40 \times-80 \times$ magnification. Specimens were picked and mounted on Curtin micropaleontologic slides for followup study and permanent preservation. Representative specimens of 


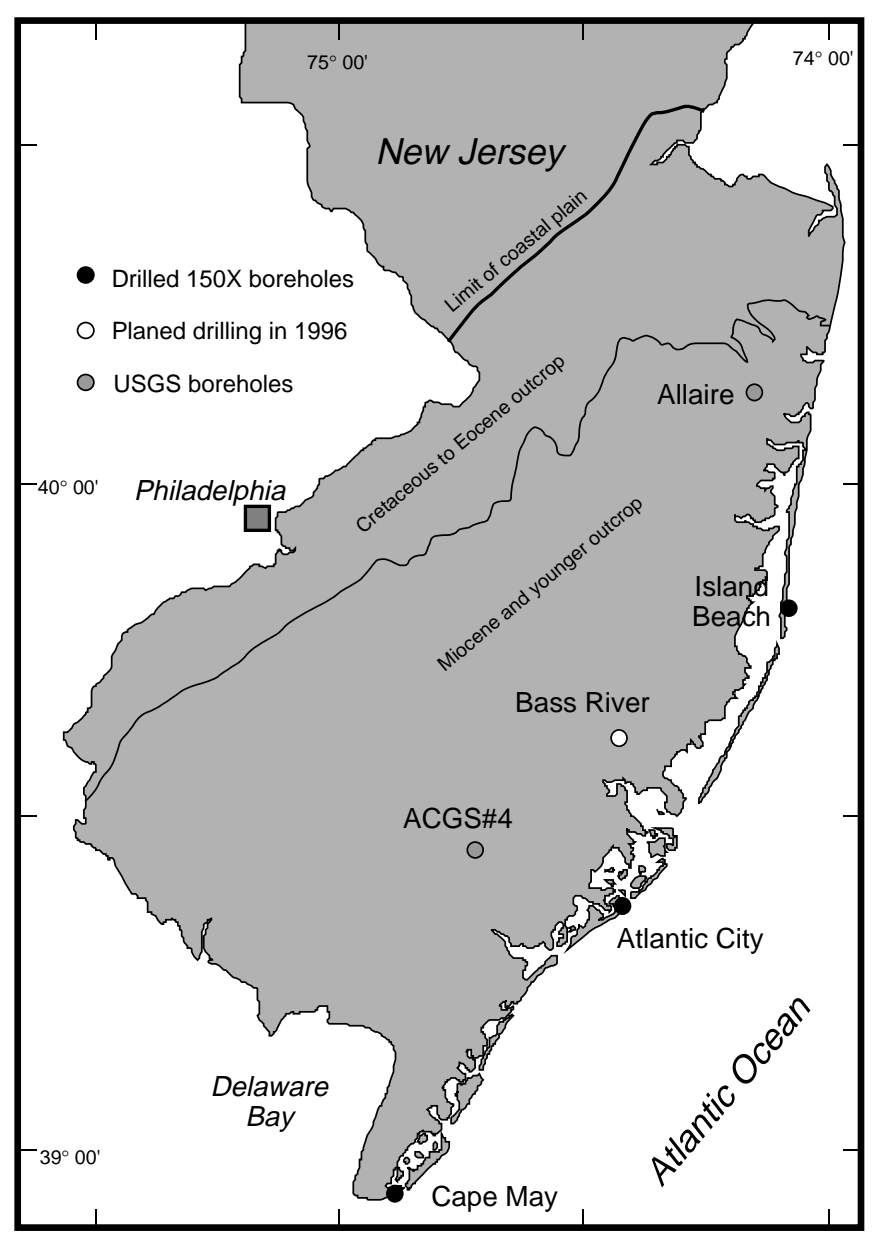

Figure 1. Location map of the New Jersey Coastal Plain Drilling, showing three ODP Leg 150X boreholes, two USGS boreholes that were previously drilled, and one borehole to be drilled in 1996.

the stratigraphically important species were examined using scanning electronic microscopy (SEM) at $300 \times$ or higher magnification to observe the details of fine architecture, and most importantly, wall texture.

The generic classification used in this study follows to a large extent that of Loeblich and Tappan (1988). Wall texture classification is also applied whenever possible (Olsson et al., 1992). Over-splitting of taxa is minimized. Some controversial taxa are defined based on type materials deposited in museum-type collections rather than by description alone, because the terminology for microscopic fine architecture has been updated significantly since the wide application of SEM techniques in micropaleontologic study.

Taphonomy may greatly affect biostratigraphic and taxonomic studies. Dissolution may remove all or at least some fragile microfossils from sediments. Recrystallization may obscure test morphology, leading to taxonomic inaccuracy and therefore an erratic biostratigraphic control. More frequently, replacement of the original test walls with pore-water calcium carbonate (in the case of planktonic foraminifers) will give a stable isotopic ( $\mathrm{Sr}, \mathrm{C}$, and $\mathrm{O}$ ) signature that differs from the original test. Unfortunately, there are no unequivocal criteria currently available for describing preservational status. We apply a five-fold preservation classification in this study:

1. Excellent (E): original wall test, without alteration and recrystallization, $>90 \%$ of empty (not infilled) and unbroken tests;
2. Good (G): original wall test, little recrystallization, $>70 \%$ unbroken tests;

3. Moderate (M): obvious recrystallization of wall tests recognized as sugary surface and color change because of deposition of calcite crystals on test surface, but without obvious dissolution, $>50 \%$ unbroken tests;

4. Poor $(\mathrm{P})$ : recrystallized, partially dissolved test walls and $>50 \%$ broken tests; and

5. Very poor (VP): heavily recrystallized and significantly dissolved tests.

In addition, we used barren (B) in Tables 1-6 for barren samples. Barren samples may result from diagenetic removal or paleoenvironmental exclusion. In preservational States 1-3, the original assemblage is preserved. In States 4 and especially 5, fragile and small planktonic foraminifers are absent due to preferential removal. In this case, when using fragile and rare species as marker taxa, bio-stratigraphic designation is not reliable. Occurrences and ranges of planktonic foraminifers are presented in a series of tables as appendices.

\section{BIOSTRATIGRAPHY}

We used the planktonic foraminiferal zonation of Berggren and coworkers (Berggren et al., 1985; Berggren and Miller, 1988; Berggren at al., 1995) exclusively as the biostratigraphic framework in this study. This framework proved to be more suitable for the Paleocene and Eocene than for the younger sediments in the onshore boreholes. The standard planktonic foraminiferal biostratigraphic schemes were established in tropical/subtropical regions. Diachronous occurrence or absence of some deeper and warmer water taxa in the temperate New Jersey shallow shelf may cause ambiguous biostratigraphic correlation. The planktonic foraminiferal biostratigraphy for the Oligocene and Miocene is therefore less accurate because of absence or rare occurrences of the marker species that to a large extent, were excluded from this temperate location. In these cases, we used secondary markers whose ranges were calibrated by Berggren et al. (1995) to the Geomagnetic Polarity Time Scale (GPTS). Nannofossil biostratigraphy, strontium stable isotopic ages, and paleomagnetic polarity chrons are also used to evaluate the reliability of the planktonic foraminiferal biostratigraphy.

\section{Island Beach}

Island Beach borehole penetrated Holocene to Upper Cretaceous sediments and is the only Leg $150 \mathrm{X}$ borehole that recovered Upper Cretaceous to lower Eocene strata.

\section{Upper Cretaceous (Navesink and Red Bank Formations)}

The Cretaceous/Tertiary (K/T) boundary was lost in an unrecovered interval between 1183.5 and $1188 \mathrm{ft}$ (360.8 and $362.2 \mathrm{~m}$ ). Approximately $35 \mathrm{ft}(10.7 \mathrm{~m})$ of Upper Cretaceous sediments were penetrated in the Island Beach borehole. A total of 27 species belonging to 11 genera were identified (Table 1). Twenty-four species disappear in the uncored interval encompassing the K/T boundary. Two taxa, Gansserina gansseri and Planoglobulina carseyae, occur only in one sample $(1200.0 \mathrm{ft}$ [365.9 m] and $1193 \mathrm{ft}$ [363.7 m]) within the Upper Cretaceous. The single occurrence of Planoglobulina carseyae may result from the Signor-Lipps effect (Signor and Lipps, 1982), whereas the earlier disappearance of the former taxon may either be caused by the same effect or its true earlier extinction as observed in some Gulf Coast, Alabama, sections (Olsson and Liu, 1994). Only one species, Guembelitria cretacea, occurs above and below the Cretaceous/Paleocene contact. Small species such as those 
Table 1. Late Cretaceous-Paleocene planktonic foraminifer ranges in the Island Beach borehole section.

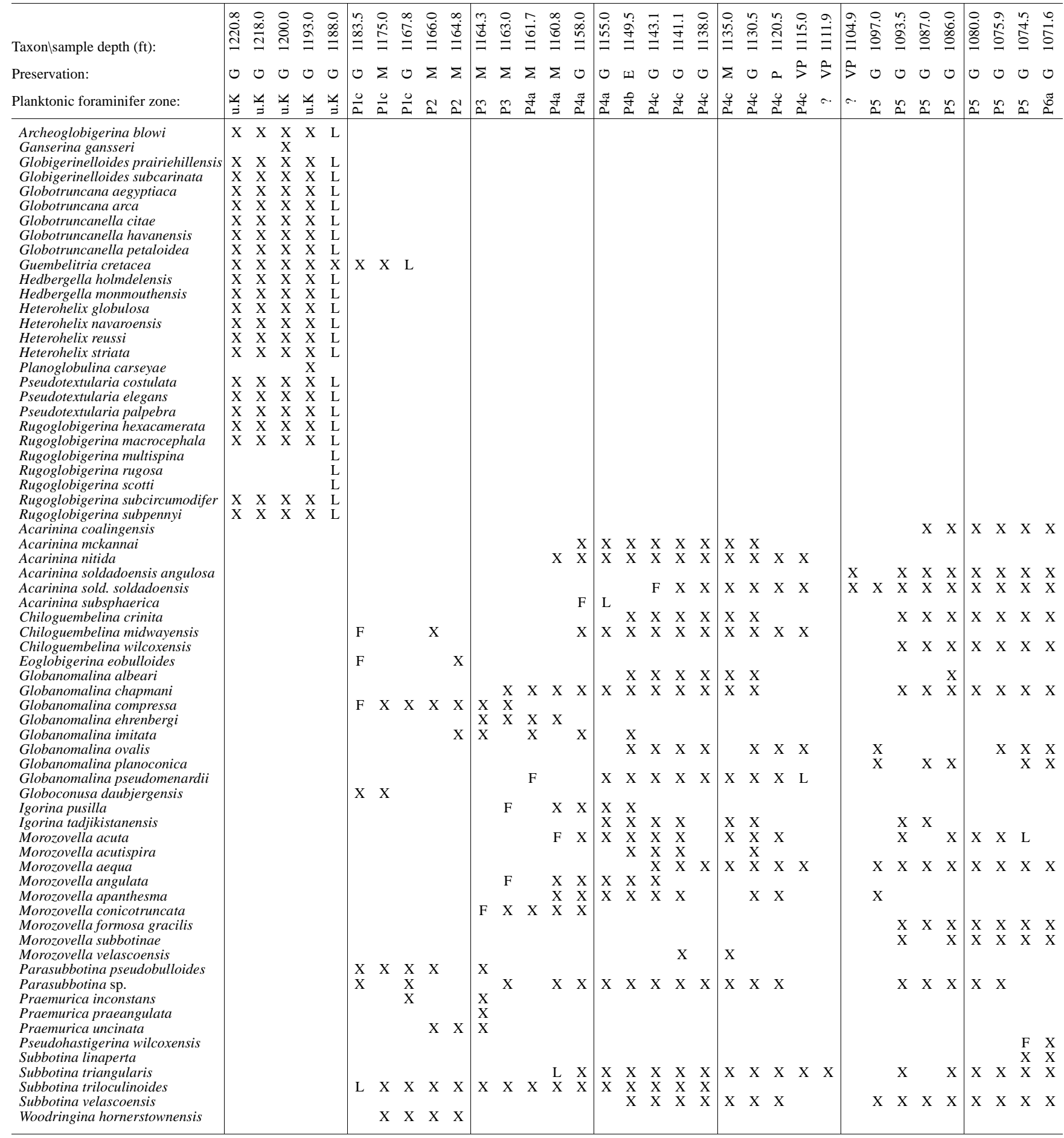

Notes: $\mathrm{E}=$ excellent $\mathrm{G}=$ good; $\mathrm{M}=$ moderate; $\mathrm{P}=$ poor; $\mathrm{VP}=$ very poor; $\mathrm{B}=$ barren; $\mathrm{F}=$ first or lowest occurrence; $\mathrm{L}=$ last or highest occurrence. $\mathrm{K}=$ Cretaceous. $\mathrm{X}=$ present.

of Heterohelix, Globigerinelloides, Rugoglobigerina, Guembelitria, and some globotruncanids are most abundant in the uppermost Cretaceous. Large taxa, typically dwellers of tropical/subtropical open marine environments (e.g., Rosita, Planoglobulina, Racemiguembelina, and Ventilabrella) are not observed. Direct biostratigraphic correlation with standard Upper Cretaceous planktonic foraminiferal zones is difficult because of the absence of the late Maastrichtian marker species Abathomphalus mayaroensis, as is the case in other uppermost Cretaceous sections in the U.S. Atlantic coast (Olsson and Wise, 1987a). The absence of this deep-water and open-ocean dweller is perhaps a result of environmental exclusion from shallow marine environments rather than an upper Maastrichtian hiatus. In fact, the 
Figure 2. Uppermost Cretaceous-Paleocene planktonic foraminiferal biostratigraphy of the Island Beach section. Ser. $=$ series; Fm. $=$ formation; Disconf. $=$ disconformity; Eoc. $=$ Eocene; 1 . Paleoc. $=$ late Paleocene; Manas. $=$ Manasquan Formation.

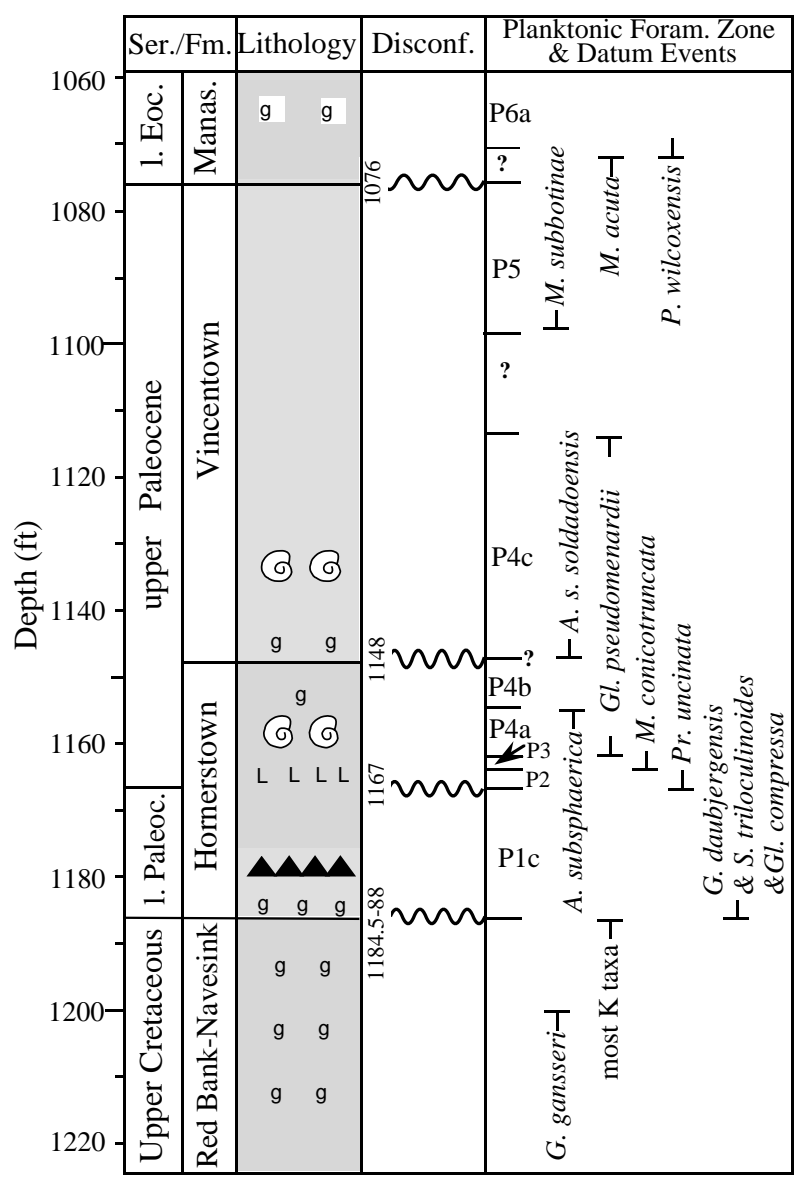

occurrence of Hedbergella monmouthensis indicates that the section at Island Beach is upper Maastrichtian (Olsson and Wise, 1987a). If the highest occurrence of Gansserina gansseri at $1200 \mathrm{ft}(365.9 \mathrm{~m})$ is a real datum level as in some Gulf Coast sections (Olsson and Liu, 1994), the interval between 1200 and $1188 \mathrm{ft}$ (365.9 and $362.2 \mathrm{~m}$ ) may correlate with the uppermost Maastrichtian.

\section{Paleocene}

Paleocene sediments were recovered only in the Island Beach borehole. Although Paleocene sediments are punctuated by possible hiatuses (Miller et al., 1994b), all Paleocene planktonic foraminiferal zones in the zonal scheme of Berggren and coworkers (Berggren and Miller, 1988; Berggren et al., 1995), except P0, P $\alpha$ and P1a-b, are recognized (Fig. 2; Table 1).

\section{Lower Paleocene (Hornerstown Formation)}

The base of Paleocene in the Island Beach borehole was recognized by the presence of a moderately preserved Danian Subzone P1c planktonic foraminiferal assemblage at $1183.5 \mathrm{ft}(360.8 \mathrm{~m})$. Three samples from 1183.5, 1175, and $1167.8 \mathrm{ft}(360.8-356.0 \mathrm{~m})$ contain Subzone P1c taxa, including Globoconusa daubjergensis, Chiloguembelina midwayensis, Eoglobigerina eobulloides, Globanomalina compressa, Parasubbotina pseudobulloides, and Subbotina triloculinoides (Table 1). The lowest occurrence (LO) of Globanomalina compressa defines the base of Subzone P1c (Berggren et al., 1995). Guembelitria cretacea also occurs in these strata. It has not been previously observed in Subzone P1c (Liu and Olsson, 1992). The presence of this species in Subzone P1c in Island Beach section may provide the linkage between this $\mathrm{K} / \mathrm{T}$ survivor to the triserial taxa in younger strata.
Two samples from 1166.0 and $1164.8 \mathrm{ft}$ (355.5 and $355.1 \mathrm{~m})$ contain a Zone P2 assemblage. Preservation of microfossils are moderate to poor because of dissolution. The marker for the base of Zone P2, Praemurica uncinata, first occurs at $1166 \mathrm{ft}$ (355.5 m; Table 1). Other taxa occurring in this sample are Chiloguembelina midwayensis, Eoglobigerina eobulloides, Globanomalina imitata, G. planocompressa, G. compressa, Parasubbotina pseudobulloides, and Subbotina triloculinoides (Table 1).

\section{Upper Paleocene (Vincentown Formation)}

Zone P3 (from the LO of Morozovella angulata and/or Igorina pusilla to the LO of Globanomalina pseudomenardii) is represented by a condensed interval. Three samples from an interval of less than $2 \mathrm{ft}(1163-1164.3 \mathrm{ft}$ [354.6-355.0 m]) contain a Zone P3 assemblage. However, this zone cannot be subdivided into subzones. According to Berggren et al. (1995), Subzones P3a and P3b are separated by the LO of Morozovella velascoensis and/or Igorina albeari. In the Island Beach borehole, the former taxon occurs only in two samples from the upper part of Zone P4. The latter taxon was not recognized. The LOs of Igorina pusilla and Morozovella angulata are at $1163.0 \mathrm{ft}$ (354.6 m). Another species, Morozovella conicotruncata, usually occurs slightly above the base of Zone P3. At Island Beach, the lowest occurrence of $M$. conicotruncata is $1.3 \mathrm{ft}(0.4 \mathrm{~m}$; at 1164.3 $\mathrm{ft}[355.0 \mathrm{~m}])$ below the lowest occurrences of Igorina pusilla and Morozovella angulata. This places the 1164.3- to 1163.0-ft interval (355.0-354.6 m) in Zone P3 equivalent. Subzone P3b is therefore either not separable from $\mathrm{P} 3 \mathrm{a}$ or represented by a hiatus in the Island Beach borehole (Fig. 2). Planktonic foraminiferal taxa occurring in this interval are displayed in Table 1.

Zone $\mathrm{P} 4$ is defined as the total range of Globanomalina pseudomenardii (Berggren and Miller, 1988; Berggren et al., 1995). Globa- 


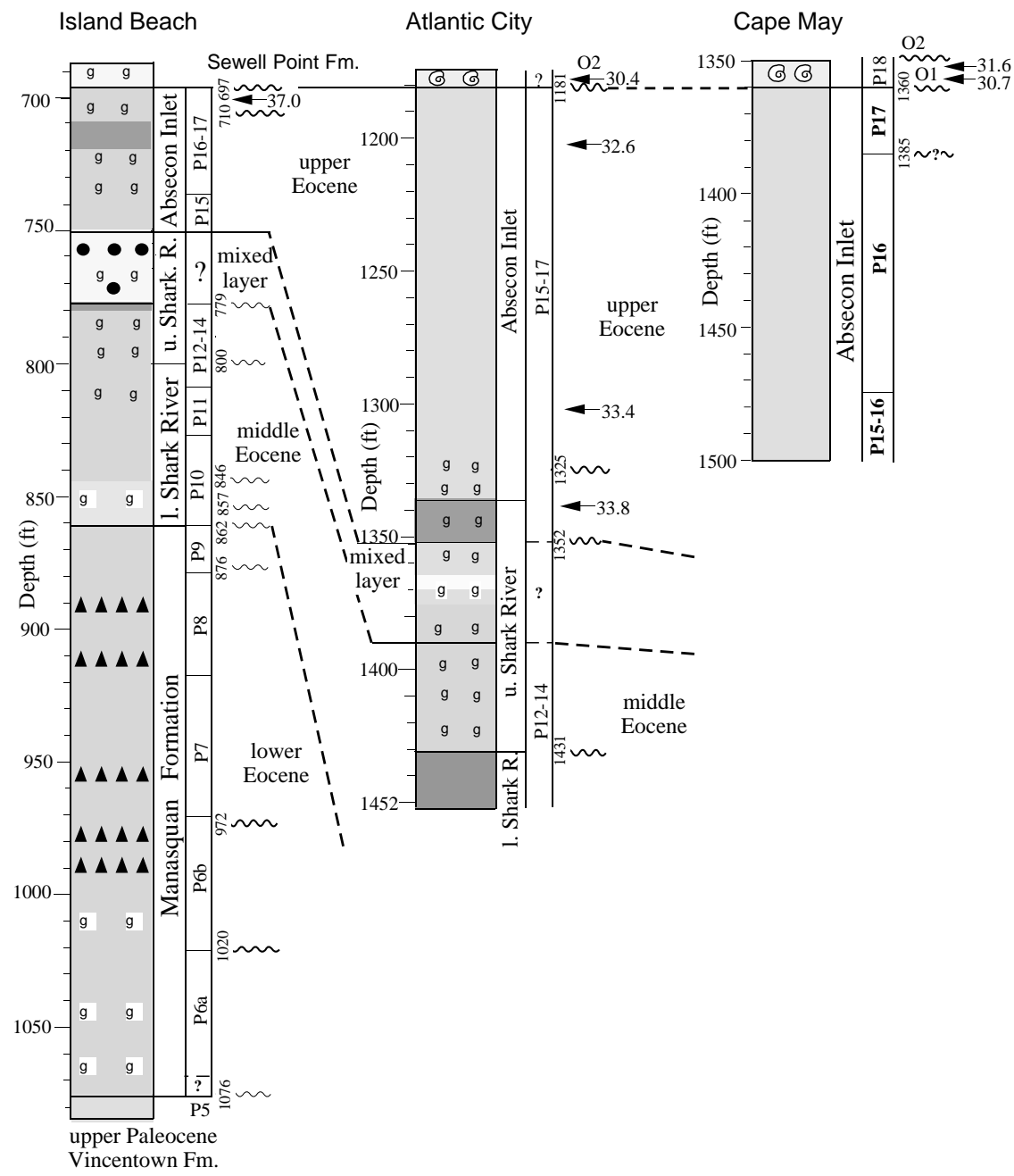

Figure 3. Stratigraphic correlation of the Eocene sediments in borehole sections at Island Beach, Atlantic City and Cape May (legend same as Fig. 1). nomalina pseudomenardii occurs in the 1161.7- to 1115.0-ft interval (354.2-339.9 m), whereas definitive Zone P5 starts at $1097 \mathrm{ft}$ (334.5 $\mathrm{m}$; discussed below). The absence of $G$. pseudomenardii in the 1111.9-1097 ft (339.0-334.5 m) interval may either be due to poor preservation of planktonic foraminifers or extinction of the taxon. Zone P4 can be further subdivided into three subzones. Subzone P4a corresponds to the total range of Acarinina subsphaerica or to the interval from the LO of $G$. pseudomenardii to the highest occurrence (HO) of Acarinina subsphaerica; the $\mathrm{HO}$ of the latter is at $1155 \mathrm{ft}$ (352.1 m). Subzone P4b extends from the $\mathrm{HO}$ of $A$. subsphaerica to the LO of A. soldadoensis; the latter appears at $1143.1 \mathrm{ft}(348.5 \mathrm{~m})$. However, only one sample (at $1149.5 \mathrm{ft}$ [350.5 m]) contains a Zone $\mathrm{P} 4 \mathrm{~b}$ assemblage. The disconformity at $1148 \mathrm{ft}(350.0 \mathrm{~m})$ is associated with the P4b/c subzonal boundary. Subzone P4c is marked by the LO of $A$. soldadoensis at base. The top of Zone $\mathrm{P} 4$ is marked by either the HO of G. pseudomenardii or the LO of Morozovella subbotinae (Berggren et al., 1995; Fig. 2).

The biostratigraphy of the 1115.0-1093.5 ft (339.9-333.4 m) interval requires additional discussion. The Zone P4 marker (Globanomalina pseudomenardii) is last observed at $1115.0 \mathrm{ft}(339.9 \mathrm{~m})$ and the LO of Morozovella subbotinae is at $1093.5 \mathrm{ft}$ (333.4 m; Table 1; Fig. 2). Three samples were studied between these levels. Among them, two (at 1111.9 and $1104.9 \mathrm{ft}$ [339.0 and $336.9 \mathrm{~m}$ ]) have very rare planktonic foraminifers, and a definitive stratigraphic designation is difficult. The sample at $1097 \mathrm{ft}(334.5 \mathrm{~m})$ is more fossiliferous but it contains neither G. pseudomenardii nor M. subbotinae. Because the Zone P4/P5 boundary is primarily defined as the $\mathrm{HO}$ of $G$. pseudomenardii, this sample should belong to Zone P5. However, the biostratigraphic zonation of the interval between 1115.0 and 1097.0 $\mathrm{ft}(352.1$ and $334.5 \mathrm{~m})$ is uncertain.

Species occurring in Zone P4 are common open-marine taxa (Table 1). The original diversity may have been higher, because dissolution may have removed some fragile species and recrystallization also makes identification of some species difficult.

Zone P5 has recently been revised by Berggren et al. (1995) from earlier definitions (Berggren et al., 1985; Berggren and Miller, 1988). It is now redefined as the interval from the HO of Globanomalina pseudomenardii to the $\mathrm{HO}$ of Morozovella velascoensis, which approximates the top of the Paleocene. As stated above, Zone P5 cannot be unequivocally separated from Zone P4 based on planktonic foraminiferal biostratigraphy alone because of the rare occurrence of microfossils between 1111.9 and $1104.9 \mathrm{ft}$ (339.0 and $336.9 \mathrm{~m}$ ) at Island Beach. Definitive Zone P5 starts at $1097.0 \mathrm{ft}$ (334.5 m; Table 1; Fig. 2 ). As a result of the rare occurrence, the observed highest occurrence of the primary marker species, M. velascoensis at $1135 \mathrm{ft}(346 \mathrm{~m})$, is apparently not the true extinction level of the taxon, and the top of Zone P5 should lie above this level in the Island Beach section. Secondary datum events for the top of Zone P5 include the HO of M. acut $a$ and LO of the Pseudohastigerina wilcoxensis. Both are in a sample at $1074.5 \mathrm{ft}(327.6 \mathrm{~m})$ in the basal Manasquan Formation. The LO of $P$. wilcoxensis is not directly calibrated to the time scale. In addition, the species concepts of $P$. wilcoxensis among workers are inconsistent, and its age is controversial (Speijer and Samir, 1997). This sample is treated as belonging to Zone P5, because it contains $M$. acuta, although nannofossil biostratigraphy (M.-P. Aubry, in Miller, et al., 1994b) indicates a basal Eocene designation. Because of improved 
preservation, the diversity of planktonic foraminiferal assemblages in Zone P5 is higher than in Zone P4 (Table 1).

\section{Eocene}

Eocene sediments were encountered in all three boreholes (Fig. $3)$. However, only in the Island Beach borehole were lower Eocene strata penetrated. Middle and upper Eocene strata were reached in the Atlantic City and Cape May boreholes.

The Eocene in the Island Beach borehole spans from $1074.5 \mathrm{ft}$ (?) to at least $697 \mathrm{ft}(327.6-212.5 \mathrm{~m})$. Planktonic foraminiferal assemblages in Eocene sediments are abundant, diverse, and generally well preserved. As a result, biostratigraphic resolution is significantly better than for Oligocene and younger strata. As in other temperate shallow marine sections, the dominant taxa are acarininids and subbotinids, whereas warm-water morozovellids are less common (Table 1). The taxa of the Turborotalia cerroazulensis lineage are common in the upper middle and upper Eocene. Pseudohastigerina, Globanomalina, Chiloguembelina, Guembelitria, and primitive globigeriniids occur frequently in finer $(63-150 \mu \mathrm{m})$ fractions.

\section{Lower Eocene (Manasquan Formation)}

The lower Eocene in the Island Beach borehole consists of $\sim 160$ $\mathrm{ft}(48.8 \mathrm{~m})$ of glauconitic silty clay that was deposited in outer neritic paleoenvironments (Browning et al., Chapter 17, this volume). All of the lower Eocene planktonic foraminiferal (sub)zones in the zonal scheme of Berggren and coworkers (Berggren et al., 1985, 1995; Berggren and Miller, 1988) were recognized, except that uppermost middle Eocene Zone P9 is not separable from basal middle Eocene Zone P10 because of the absence of Hantkenina nuttalli (the LO of $H$. nuttalli defines the base of Zone P10 and approximates the lower/ middle Eocene boundary).

Planktonic foraminiferal biostratigraphy places the base of Zone P6 and the base of the Eocene above the HO of Morozovella acuta at $1074.5 \mathrm{ft}$ ( $327.6 \mathrm{~m}$, discussed above). The top of Zone P6 occurs between 981 and $975 \mathrm{ft}$ (299.1 and $297.3 \mathrm{~m}$ ), where the Zone P7 marker species $M$. aragonensis first appears. Zone P6 is divided into two subzones (P6a and P6b) based on the LO of M. formosa formosa at $1018.0 \mathrm{ft}(310.4 \mathrm{~m})$. Preservation of foraminifers is moderate because of infilling of calcite crystals within tests and/or calcite overgrowth on the test surface. Nearly 30 taxa were recognized in this interval (Fig. 3; Table 2).

Zone $\mathrm{P} 7$ is recognized as the interval from the LO of Morozovella aragonensis to the $\mathrm{HO}$ of $M$. formosa formosa at $882 \mathrm{ft}$. (268.9 m). A slight diversity decrease is observed in this interval. This decrease is caused by the extinction of some acrininid, globanomalinid, morozovellid, and subbotinid species that evolved during the middle Paleocene (Zone P3-4) radiation (Table 2). Preservation of microfossils is moderate, similar to the Zone P6 assemblages.

Zone P8 is by definition a gap zone that ranges from the highest occurrence of Morozovella formosa formosa to the lowest appearance of Planorotalites palmerae. The former is at $882 \mathrm{ft}(268.9 \mathrm{~m})$ and only one specimen of the latter was observed at $875 \mathrm{ft}(266.8 \mathrm{~m})$. Therefore, only two samples (879 and $878.3 \mathrm{ft}$ [268.0 and $267.8 \mathrm{~m}$ ]) represent Zone $\mathrm{P} 8$ in this borehole.

The base of Zone P9 is defined by the LO of Planorotalites palmerae, and the top of Zone P10 is the LO of Globigerinatheka mexicana kugleri. These two zones are separated by the LO of Hantkenina nuttalli (Berggren and Miller, 1988; Berggren et al., 1995). This zonal boundary corresponds to the lower/middle Eocene boundary. The single specimen of Planorotalites palmerae was observed at $875 \mathrm{ft}$ (266.8 $\mathrm{m}$ ), whereas $H$. nuttalli is absent from the Island Beach borehole (Table 2). It is therefore impossible to separate Zone P9 from P10 and, thus, the lower/middle Eocene boundary cannot be precisely located by planktonic foraminiferal biostratigraphy. There is a sharp lithologic change from firm shelf clay (Manasquan Formation) to middle neritic glauconitic sand and sandy clay (lower Shark River Fm.) at $861.8 \mathrm{ft}(262.7 \mathrm{~m})$ and an additional disconformity at $857 \mathrm{ft}$ (261.3 m; Fig. 3; Browning et al., Chapter 17, this volume). Based on integrated magnetobiostratigraphy which places the Chron C22n/ C21r boundary near $857-855 \mathrm{ft}(261.3-260.7 \mathrm{~m})$, the latter break correlates with the Zone P9/P10 and lower/middle Eocene boundaries (Browning et al., Chapter 17, this volume). Planktonic foraminiferal assemblages are diverse in the Manasquan Formation outer neritic clays, but diversity drops significantly in middle-outer neritic glauconitic sands of the lower Shark River Formation (Table 2).

\section{Middle Eocene (Shark River Formation)}

The middle Eocene in the Island Beach borehole consists of $\sim 83$ $\mathrm{ft}(25.3 \mathrm{~m})$ of middle-outer neritic sediments. All middle Eocene (sub)zones in the zonal scheme of Berggren and coworkers (Berggren et al., 1985, 1995; Berggren and Miller, 1988) are recognized, although some zones (P13/14) are not differentiated due to the absence of marker species (Fig. 3). There is a significant diversity decrease in planktonic foraminiferal assemblages from at least 14 to approximately nine species from the early to middle Eocene. Taxa that disappear include mostly acrininids and morozovellids. This change in diversity results from a shallowing from outer to middle neritic paleoenvironments. Poor preservation (recrystallization in porcellanite) is another factor affecting diversity in some New Jersey middle Eocene sections (e.g., ACGS\#4; Poore and Bybell, 1988; Miller et al., 1990), although porcellanites are restricted primarily to the lower Eocene at Island Beach (Table 2).

The Zone P10/P11 boundary is between 825.0 and $820.9 \mathrm{ft}(251.5$ and $250.3 \mathrm{~m}$ ) based on the LO of Globigerinatheka mexicana kugleri in a single sample at $820.9 \mathrm{ft}$ (250.3 m; Fig. 3). Taxa identified in Zone P10 include Acarinina bullbrooki, Chiloguembelina crinita, Planorotalites renzi, Pseudohastigerina wilcoxensis, Subbotina frontosa, S. linaperta, and S. lozanoi (Table 2).

Zone P11 extends from the LO of Globigerinatheka mexicana kugleri at $820.9 \mathrm{ft}(250.3 \mathrm{~m})$ to the $\mathrm{HO}$ of Morozovella aragonensis at $809.0 \mathrm{ft}(246.6 \mathrm{~m})$. Diversity increases slightly mainly because of occurrences of additional morozovellid species and improved preservation. Taxa include Acarinina bullbrooki, Chiloguembelina crinita, Globigerinatheka subconglobata subconglobata, Guembelitria columbiana, Morozovella aragonensis, M. spinulosa, Pseudohastigerina wilcoxensis, Subbotina frontosa, and S. linaperta (Table 2).

Zone P12 in the Island Beach borehole is characterized by excellent preservation and a diverse assemblage of planktonic foraminifers. The zone was defined (Berggren et al., 1995) on the HO of Morozovella aragonensis to the LO of Globigerapsis beckmanni. The former is at $809 \mathrm{ft}(246.6 \mathrm{~m})$, whereas the latter was not observed in the three boreholes. Because of the absence of Globigerapsis beckmanni, whose HO defines the top of Zone P13, Zones P13 and P14 are not separable at Island Beach borehole. According to Berggren et al. (1995), the HO of Acarinina bullbrooki is equivalent to the LO of G. beckmanni at $40.5 \mathrm{Ma}$ in Chron C18r. The HO of A. bullbrooki is used as an alternative for the base of Zone P13 equivalent. At Island Beach, the abrupt disappearance of this species occurs between 767 and $762 \mathrm{ft}$ (233.8 and $232.3 \mathrm{~m}$; Table 2; Fig. 3), marking the base of Zone $\mathrm{P} 13$ equivalent.

The base of Zone P15 is defined by the LO of Porticulasphaera semiinvoluta, which is at $750 \mathrm{ft}(228.7 \mathrm{~m})$ at Island Beach. The HO of Morozovella spinulosa at $757 \mathrm{ft}(230.8 \mathrm{~m})$, which should be slightly younger than the LO of $P$. semiinvoluta, indicates a Zone P14 or basal P15 equivalent (Fig. 3; Table 2). This abnormal sequence of datum events can be explained differently. One possibility is that the delayed LO of $P$. semiinvoluta is caused by the Signor-Lipps effect (Signor and Lipps, 1982), because only two samples in the whole section contain this species. The other explanation is that this section 


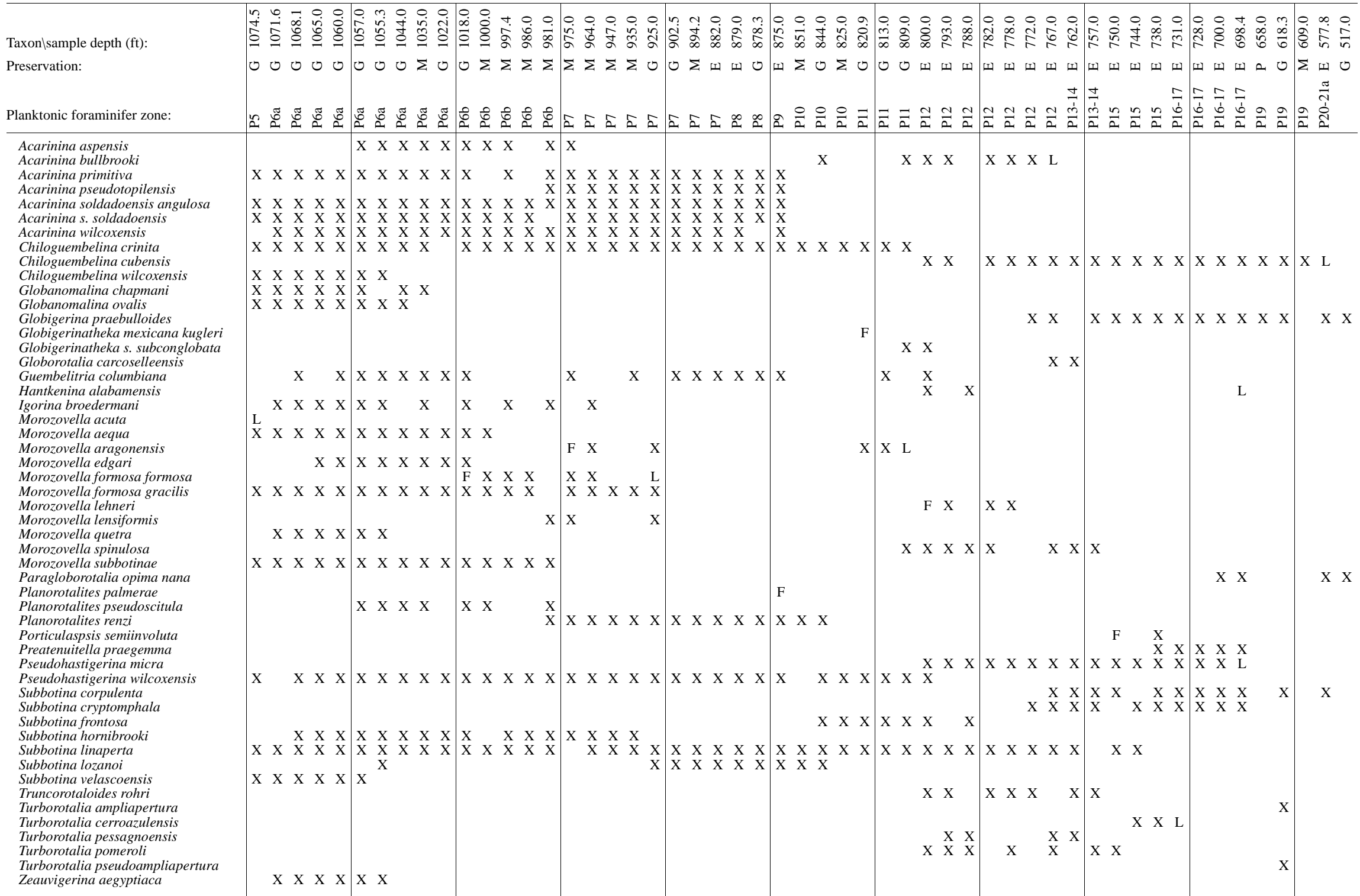

Note: See Table 1 for definitions. 
suffers from stratigraphic mixing that results from reworking, an interpretation supported by nannofossil studies (Miller et al., 1994b; Browning, et al., Chapter 16, this volume) and regional correlations (see Snyder et al., 1996). According to M.-P. Aubry (in Miller et al., $1994 \mathrm{~b})$, the $779-750 \mathrm{ft}(237.5-228.7 \mathrm{~m})$ interval is stratigraphically mixed. Zone NP19-20 nannofossil species (such as Isthmolitus recurvus) co-occur with the NP17-18 nannofossil assemblage (M.-P. Aubry, in Miller et al., 1994b). Based on the mixed occurrence of nannofossils, the upper part of the Shark River Formation at Island Beach (779-750 ft [237.5-228.7 m]) and at Atlantic City (1390$1352 \mathrm{ft}$ ) is considered a mixed layer (Miller et al., 1994b; Fig. 3). A mixed layer of this age has been found in several places along the North Atlantic coast and slope sections and is interpreted as the Exmore impact breccia (Poag and Aubry, 1995). If this is indeed the case, this interval contains mixed Zone P14-15 microfossil assemblages, and the abnormal datum events can be explained.

\section{Upper Eocene (Absecon Inlet Formation)}

Zone 15 straddles the middle/upper Eocene boundary. The upper Eocene includes the upper part of Zone P15 and Zones P16 and P17. None of the three zones can be precisely separated by primary markers at Island Beach because of the absence of Cribrohantkenina infla$t a$, whose total range defines Zone P16. According to Berggren et al. (1995), the HO of Porticulasphaera semiinvoluta is slightly younger than the LO of Cribrohantkenina inflata (35.3 vs. $35.5 \mathrm{Ma}$ ). The former was observed at $738 \mathrm{ft}(225.0 \mathrm{~m})$. Therefore, the 750 - to 738 $\mathrm{ft}$ interval is assigned to Zone P15 equivalent based on a secondary criterion. In the zonal scheme of Berggren and coworkers (Berggren and Miller, 1988; Berggren et al., 1995), the highest occurrence of Turborotalia cerroazulensis defines the base of Zone P18, which approximates the Eocene/Oligocene boundary. In the Island Beach borehole, this event is at $731 \mathrm{ft}(222.9 \mathrm{~m})$. However, specimens of Hantkenina alabamensis were found from a sample at $698.4 \mathrm{ft}(212.9$ $\mathrm{m})$. The HO of Hantkenina alabamensis should slightly postdate the HO of Turborotalia cerroazulensis, as it does at the stratotype section at Massignano (Coccioni et al., 1988). The $\mathrm{HO}$ of $H$. alabamensis is used here to recognize the Eocene/Oligocene boundary. Therefore, Zones P16-17, and thus the upper Eocene, range to $698.4 \mathrm{ft}(212.9$ $\mathrm{m}$ ) in the borehole (Fig. 3).

\section{Oligocene (Sewell Point and Atlantic City Formations)}

Most Oligocene samples from the Island Beach boreholes are barren or contain scarce planktonic foraminifers (Table 2). The basal Oligocene planktonic foraminiferal Zone P18 is defined on the $\mathrm{HO}$ of Turborotalia cerroazulensis to the $\mathrm{HO}$ of Pseudohastigerina micra by Berggren and coworkers (Berggren and Miller, 1988; Berggren et al., 1995). The HO of Pseudohastigerina micra and the HO of Hantkenina alabamensis are in the same sample at $698.4 \mathrm{ft}(212.9 \mathrm{~m})$, and this sample is assigned to Zone P17, as discussed above. The absence of taxa that indicate Zone P18 may suggest a basal Oligocene hiatus. Nevertheless, application of absence criteria in these poorly fossiliferous strata should be taken with caution. Samples below $658 \mathrm{ft}$ and above $697 \mathrm{ft}$ ( 200.6 and $212.5 \mathrm{~m}$ ) are not fossiliferous, and their biostratigraphy is therefore equivocal. A sample at $658 \mathrm{ft}(200.6 \mathrm{~m})$ does not contain Pseudohastigerina micra and other diagnostic taxa, which would suggest an age younger than Zone P18. The single occurrence of Turborotalia ampliapertura at $618.3 \mathrm{ft}(188.5 \mathrm{~m})$ places this sample and the 658- to 618.3-ft interval (200.6-188.5 m) in Zone P19. Sr-isotopic results of $31.1-31.5 \mathrm{Ma}$ in the lower Absecon Inlet Formation between 750 and $697 \mathrm{ft}(228.7$ and $212.5 \mathrm{~m})$ also point to a Zone P19 equivalent age (Fig. 4).

The early/late Oligocene boundary, which is also the Zone P21a/ $\mathrm{P} 21 \mathrm{~b}$ boundary, is marked by the HO of Chiloguembelina cubensis, which is at $577.8 \mathrm{ft}(176.2 \mathrm{~m})$. This sample can be assigned to either
Zone P20 or Subzone P21a. The next fossiliferous sample at $517 \mathrm{ft}$ $(157.6 \mathrm{~m})$ has no stratigraphically diagnostic taxa. It should be late Oligocene based on strontium isotope results (Pekar et al., Chapter 15, this volume; Table 2; Fig. 4). The 517- to 577.8-ft interval (157.6-176.2 m) cannot be zoned because of lack of microfossils.

All stratigraphically younger samples from the Island Beach borehole do not bear age-diagnostic taxa, and planktonic foraminiferal biostratigraphic correlations are not possible.

\section{Atlantic City}

\section{Middle Eocene (Shark River Formation)}

The Eocene in the Atlantic City borehole spans from the base of the core $(1452 \mathrm{ft}[442.7 \mathrm{~m}])$ to $1181 \mathrm{ft}(360.1 \mathrm{~m})$. The absence of Morozovella aragonensis (whose HO defines the base of Zone P12) from the oldest sample at $1451.8 \mathrm{ft}(442.6 \mathrm{~m})$ indicates a Zone P12 or younger age. Other evidence supporting this age assignment is the presence of M. lehneri and Turborotalia cerroazulensis pomeroli at the base of the borehole (1451.8 ft; Table 3). According to Berggren et al. (1985), the first occurrence of M. lehneri (43.5 Ma) and the last occurrence of M. aragonensis (43.6 Ma) are nearly synchronous, and the first occurrence of $T$. cerroazulensis pomeroli is younger than both. Recognition of an advanced specimen of M. lehneri and T. cerroazulensis pomeroli at $1451.8 \mathrm{ft}(442.6 \mathrm{~m})$ places the base of the borehole in the lower part of Zone P12 equivalent (Fig. 3). As at Island Beach, the Zone P13 marker species, Globigerapsis beckmanni, is absent. Therefore, Zones P12-14 are not differentiated. The abundant occurrence of Acarinina bullbrooki (which disappears elsewhere at the level of the LO of G. beckmanni) to $1352 \mathrm{ft}(412.2 \mathrm{~m})$ suggests an equivalence of Zone P12 age from the base to this level. However, the 1390- to 1352-ft interval (423.8-412.2 m) at Atlantic City correlates with the mixed layer $(779-750 \mathrm{ft})$ at Island Beach. The microfossil assemblages consist of reworked and in situ taxa. The possibility of the 1352- to 1390-ft interval (412.2-423.8 m) belonging to Zone P15 cannot be ruled out. Nannofossils indicate that the section above $1390 \mathrm{ft}(423.8 \mathrm{~m})$ may be upper Eocene (Zone ?NP18 or NP19-20; M.-P. Aubry in Miller et al., 1994b) and are thus equivalent to Zone $\mathrm{P} 15$ or younger.

A surface at $1352 \mathrm{ft}(412.2 \mathrm{~m})$ separates definite Zone P15 (silty clay) below from the mixed interval (glauconitic clayey sands) above. The species of Acarinina, Morozovella, Planorotalites, and Truncorotaloides show abrupt disappearances at this hiatus (Table 3; Fig. 3). These sudden disappearances support the scenario of a mixed layer of impact origin.

\section{Upper Eocene (Absecon Inlet Formation)}

The base of Zone P15 (upper middle Eocene) is marked by the LO of Porticulasphaera semiinvoluta and the sudden disappearance of the species of Acarinina, Morozovella, Planorotalites, and Truncorotaloides at $1348 \mathrm{ft}$ (411.0 m; Table 3). As at Island Beach, the upper Eocene (approximately Zones P15-17) at Atlantic City cannot be divided into the standard planktonic foraminiferal zones because of the absence of Cribrohantkenina inflata (marker for the total range Zone P16) in the section. According to Berggren et al. (1995), three other bioevents are slightly younger than this event and can be used to approximate the base of Zone P16 equivalent: the HOs of Porticulasphaera semiinvoluta and Turborotalia pomeroli followed by the LO of $T$. cunialensis. In the Atlantic City borehole, these events occur in the expected order (i.e., at 1288, 1295, and $1265 \mathrm{ft}[392.7,394.8$, and $385.7 \mathrm{~m}]$ ). We approximate the base of Zone P16 by using the $\mathrm{HO}$ of T. pomeroli because this species is the most common taxon. The HO of Globigerapsis index is at $1187.3 \mathrm{ft}(362.0 \mathrm{~m})$. This datum event should be slightly older ( 34.3 vs. $34.0 \mathrm{Ma}$ ) than the LO of Cribrohantkenina inflata (= the top of Zone P16; Berggren et al., 1995). The next sample at $1182.7 \mathrm{ft}(360.4 \mathrm{~m})$ is the youngest one containing a 
late Eocene planktonic foraminiferal assemblage and the only one containing a Zone P17 assemblage. Very likely, Zone P17 is not fully developed at this site or the equivalent strata representing it were eroded away during the formation of the Eocene/Oligocene disconformity at $1181 \mathrm{ft}(360.1 \mathrm{~m})$. The Eocene/Oligocene boundary corresponds to the depositional hiatus at $1181 \mathrm{ft}(360.1 \mathrm{~m})$. Up to 48 taxa are recognized in the upper Eocene in this borehole (Table 3).

\section{Lower Oligocene (Sewell Point Formation)}

The lower Oligocene at Atlantic City spans the 1181- to 1104-ft interval (360.1-336.6 m). The early Oligocene planktonic foraminiferal assemblage in this borehole, as at Island Beach, is characterized by a significant diversity drop of more than half of the Eocene taxa (>40 to $\sim 20$ species). The survivors are mostly small, oligotrophic, long-ranging taxa. Owing to a more oceanic depositional environment, the diversity of planktonic foraminiferal assemblages in Atlantic City borehole Oligocene is much higher than that at Island Beach (Table 4).

The basal Oligocene (1181-1178 ft [360.1-359.1 m]) is barren of planktonic foraminifers. The poorly preserved assemblage from 1178 $\mathrm{ft}(359.1 \mathrm{~m})$ contains no diagnostic planktonic foraminiferal species. The fossiliferous interval from 1175 to $1139 \mathrm{ft}(358.2-347.3 \mathrm{~m})$ contains a moderately preserved assemblage. This interval is probably equivalent to either Zone P19 or P20. As pointed out earlier, absence criteria are not reliable for zonation of these poorly fossiliferous strata. The initial occurrence of Tenuitella juvenilis at $1145 \mathrm{ft}(349.1 \mathrm{~m})$ may indicate the presence of early Oligocene Zone P20. Sr-isotopic results (30.4 Ma at $1178.2 \mathrm{ft}[359.2 \mathrm{~m}] ; 28.1 \mathrm{Ma}$ at $1164.5 \mathrm{ft}[355.0$ m]; 28.3 Ma at $1140.9 \mathrm{ft}$ [347.8 m]; Pekar et al., Chapter 15, this volume) are also consistent with an early Oligocene age at this level. The planktonic foraminiferal assemblage is characterized by oligotrophic taxa such as the species of Globigerina, Globorotaloides, Tenuitella, and Paragloborotalia opima nana (Table 4).

Subzone P21a spans the interval from the LO of Globigerina angulisuturalis to the HO of Chiloguembelina cubensis. Those two datum events embrace the 1135.0- to 1109.0-ft interval (346.0-338.1 $\mathrm{m})$ at Atlantic City. The planktonic foraminiferal assemblage is similar to that of Zone P19-20 with small species, such as those of Chiloguembelina, Globigerina, Subbotina, and Tenuitella, as major components (Table 4; Fig. 4).

\section{Upper Oligocene (Atlantic City Formation)}

The upper Oligocene lies between 1109 and $914 \mathrm{ft}$ (338.1 and $278.7 \mathrm{~m}$ ), where a hiatus separates the upper Oligocene Atlantic City Formation from the lower Miocene Kirkwood Formation. This is the thickest upper Oligocene section of the three Leg 150X boreholes. Subzone P21b ranges between $1109 \mathrm{ft}$ (338.1 m; HO of Chiloguembelina cubensis) and $1078.0 \mathrm{ft}$ (328.7 m; HO of Paragloborotalia opima opima) (Fig. 4). Preservation of microfossils is moderate. A total of 13 taxa are recognized, and they are mostly long-ranging globigeriniids. (Table 4 ).

Zone P22 spans from 1072.9 to $914 \mathrm{ft}(327.1-278.7 \mathrm{~m})$, the thickest of all three Leg 150X sites. Preservation of microfossils ranges from poor to good. Diversity is relatively low (a total of 23 taxa) because of deposition in an inner to middle neritic paleoenvironment (Pekar et al., Chapter 15, this volume). Globorotaloids, primitive globorotaliids, tenuitellids, and globigerinids are the common forms. The upper Oligocene and lower Miocene strata are not separable biostratigraphically because of lack of marker taxa. The occurrence of Subbotina euapertura at $920.0 \mathrm{ft}(280.5 \mathrm{~m})$ suggests a Zone P22 age at this level. Sr-isotopic age estimates indicate that a disconformity at $914.4 \mathrm{ft}(278.7 \mathrm{~m})$ marks the Oligocene/Miocene boundary (Pekar et al., Chapter 15 , this volume).

\section{Miocene}

\section{Lower Miocene (Kirkwood Formation)}

Sr-isotopic studies (Miller, et al., 1994a; Miller et al., 1994b; Miller and Sugarman, 1995; Sugarman et al., Chapter 12, this volume) indicate that the lower Miocene (914.4-512 ft [278.8-156.1 $\mathrm{m}]$; Kw0 through $\mathrm{Kw} 2 \mathrm{a}$ sequences) is separated from the middle Miocene by a disconformity at $512 \mathrm{ft}(156.1 \mathrm{~m})$. The lower part of the lower Miocene (888-820 ft [270.7-250.0 m]) contains a wellpreserved early Miocene planktonic foraminiferal assemblage. The middle 810- to 666-ft interval (247.0-203.0 m; Kw1a-b sequences) contains few planktonic foraminifers. The upper $(666-512 \mathrm{ft}$ [203.0-156.1 m]) inner shelf silty clay (Kw 2a) contains a low diversity, but well-preserved early Miocene planktonic foraminiferal assemblage. Most members of the early Miocene assemblage are nondiagnostic taxa such as those of Catapsydrax, Globigerina, Globigerinoides, primitive Globorotalia, and Globoquadrina. As such,

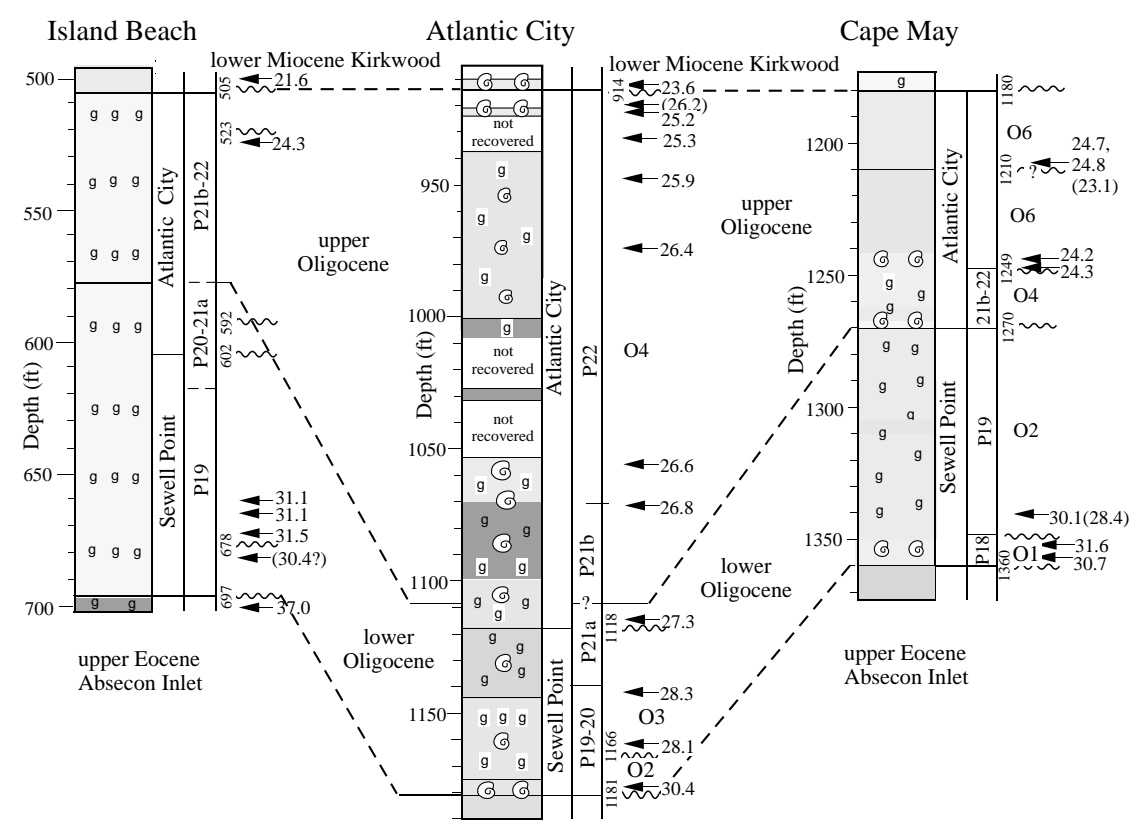

Figure 4. Stratigraphic correlation of the Oligocene sediments in borehole sections at Island Beach, Atlantic City and Cape May (legend same as Figure 1). 
Table 3. Eocene planktonic foraminifer ranges in the Atlantic City borehole section.

Taxonlsample depth (ft):

Preservation:

Planktonic foraminifer zone:

Acarinina bullbrooki

Acarinina crassata

Acarinina densa

Acarinina mathewsae

Acarinina primitiva

Acarinina pseudotopilensis

Acarinina spinuloinflata

Cassigerinella winniana

Catapsydrax dissimilis

Catapsydrax unicavus

Chiloguembelina cubensis

Chiloguembelina victoriana

Globigerina(?) medizzai

Globigerina praebulloides leroyi

Globigerina p. praebulloides

Globigerinatheka mexicana

Globigerinatheka senni

Globigerinatheka subconglobata

micra

Globigerinatheka subconglobata

Globigerapsis index

Globorotalia increbescen

Globorotaloides suteri

Guembelitria columbiana

Hantkenina dumblei

Hantkenina liebusi

Hantkenina primitiva

Igorina broedermani

Morozovella lehneri

Morozovella spinulosa

Paragloborotalia opima nana

Planorotalites pseudoscitula

Praetenuitella praegemma

Pseudohastigerina micra

Pseudohastigerina sharkriverensis

Subbotina angiporoides

Subbotina corpulenta

Subbotina cryptomphala

Subbotina frontosa

Subbotina galavisi

Subbotina linapert

Subbotina lozanoi

Subbotina tapuriensis

Tenuitella clemenciae

Tenuitella gemma

Truncorotaloides collactea

Truncorotaloides libyaensis

Truncorotaloides rohri

Truncorotaloides topilensis

Turborotalia ampliapertura

Turborotalia bolivariana

Turborotalia cerroazulensi

Turborotalia cocoaensis

Turborotalia possagnoensis

Turborotalia pomeroli

Turborotalia pseudoampliapertura

?Turborotalia wilsoni
Globigerina(?) danvillensi

Globorotaloides carcoselleensis

Hantkenina alabamensis

Porticulasphaera semiinvolut

Subbotina eocaena

Subbotina euapertura

Turborotalia cunialensis

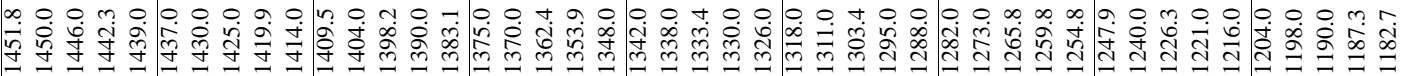

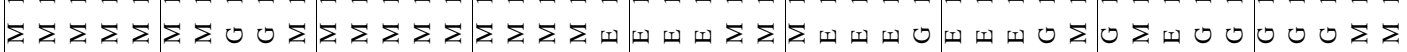
$\frac{N}{a} \frac{N}{a} \frac{N}{a} \frac{N}{a} \frac{N}{a} \frac{N}{a} \frac{N}{a} \frac{N}{a} \frac{N}{a} \frac{N}{a} \frac{N}{a} \frac{N}{a} \frac{n}{a} \frac{n}{a} \frac{n}{a} \frac{n}{a} \frac{n}{a} \frac{n}{a} \frac{n}{a} \frac{0}{a} \frac{0}{a} \frac{0}{a} \frac{0}{a} \frac{0}{a} \frac{0}{a} \frac{0}{a} \frac{0}{a} \frac{0}{a} \frac{0}{a} \frac{0}{a} \frac{0}{a} \frac{0}{a} \frac{}{a}$

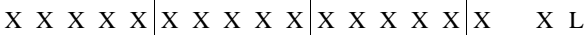

$\begin{array}{llllllllllllllllllllllllllll}\mathrm{X} & \mathrm{X} & \mathrm{X} & \mathrm{X} & \mathrm{X} & \mathrm{X} & \mathrm{X} & \mathrm{X} & \mathrm{X} & \mathrm{X} & \mathrm{X} & \mathrm{X} & \mathrm{X} & \mathrm{X} & \mathrm{X} & \mathrm{X} & \mathrm{X} & \mathrm{X} & \mathrm{L}\end{array}$

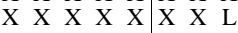

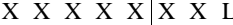

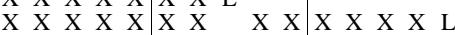

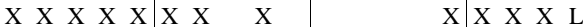

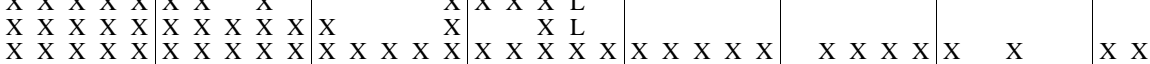

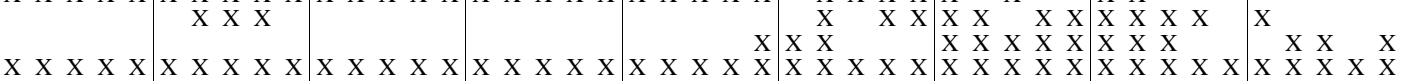

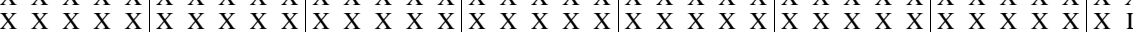

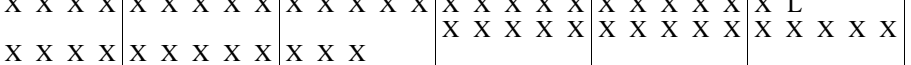

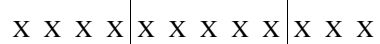

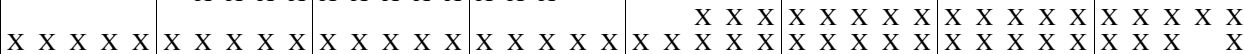

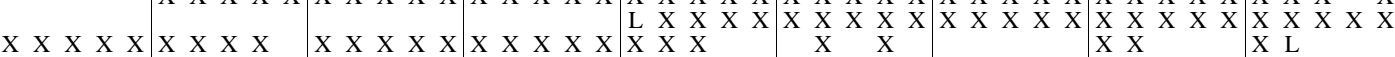

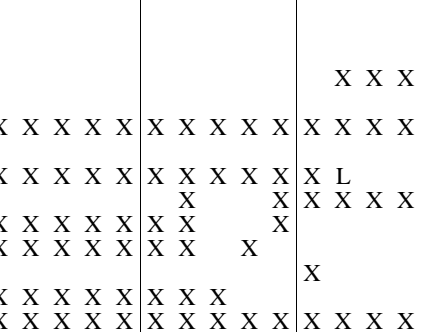

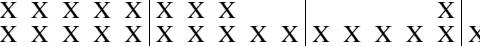

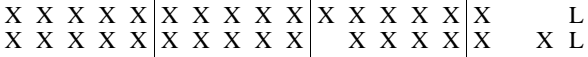

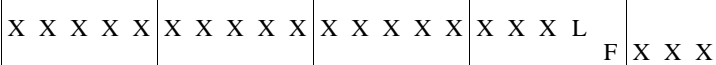

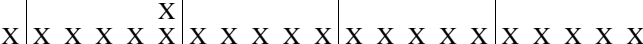

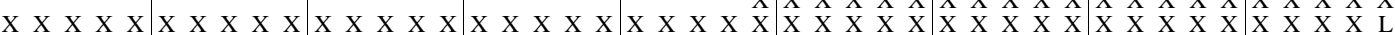

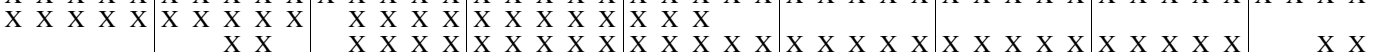

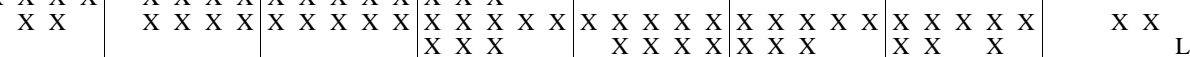

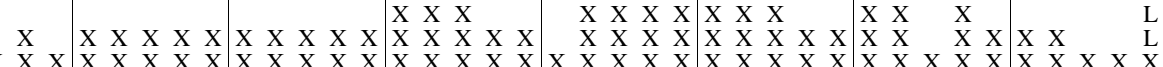

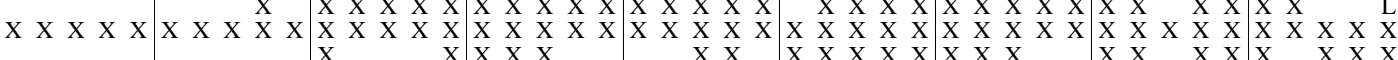

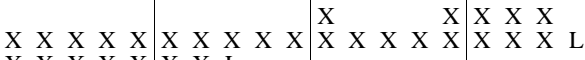

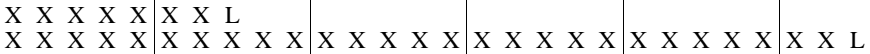

$\mathrm{X}$

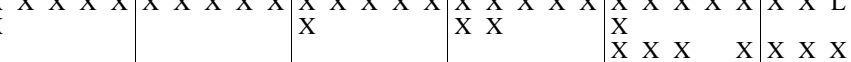

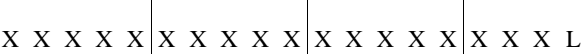

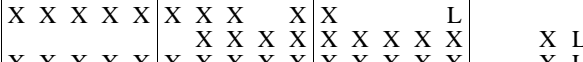

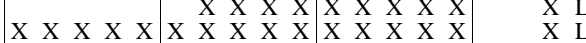

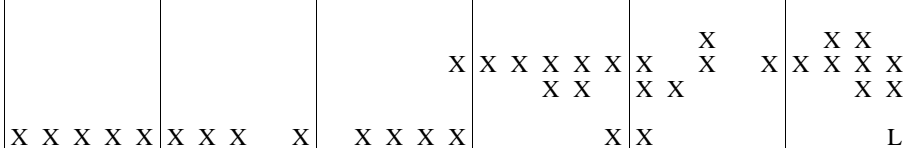

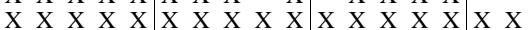

$\begin{array}{llllllllll}\mathrm{X} & \mathrm{X} & \mathrm{X} & \mathrm{X} & \mathrm{X} & \mathrm{X} & \mathrm{X}\end{array}$

$\begin{array}{lllllllllllllll} & X & X & & \end{array}$

$\mathrm{X} \times \mathrm{X}$

L

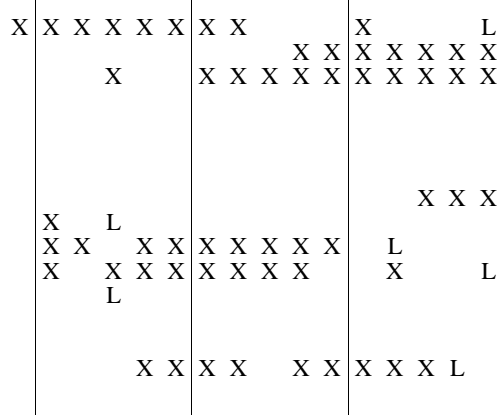

Note: See Table 1 for definitions

biostratigraphy cannot go beyond recognizing that the strata are lower Miocene. (Table 4).

\section{Middle Miocene (Kirkwood Formation 2b, 3 and Cohansey Formation?)}

The top of the middle Miocene at Atlantic City is tentatively placed at the $232 \mathrm{ft}(70.7 \mathrm{~m})$ disconformity based on lithostratigraphic correlation (Miller et al., 1994a). The middle Miocene is therefore $280 \mathrm{ft}$ thick $(85.4 \mathrm{~m}$, from 512 to $232 \mathrm{ft}$ [156.1-70.7 m]) at this site. The lower part (512-410 ft [156.1-125.0 m]) has few planktonic foraminifers because of deposition in shallow inner shelf paleoenvironment, as evidenced by low diversity of benthic foraminifers and a vir- tual absence of planktonic foraminifers. The upper part (410-232 ft [125.0-70.7 m]), including the unrecovered interval from 291 to 391 $\mathrm{ft}(90.5-119.2 \mathrm{~m})$, is predominantly quartzose fine to medium sand, which was deposited in a marginal marine environment. Diagnostic planktonic foraminiferal species were not observed in this interval.

\section{Cape May}

\section{Eocene}

\section{Upper Eocene (Absecon Inlet Formation)}

Coring at Cape May ended at $1500 \mathrm{ft}(457.3 \mathrm{~m})$ within the newly named upper Eocene Absecon Inlet Formation (Browning et al., 
Table 4. Oligocene-Miocene planktonic foraminifer ranges in the Atlantic City borehole section.

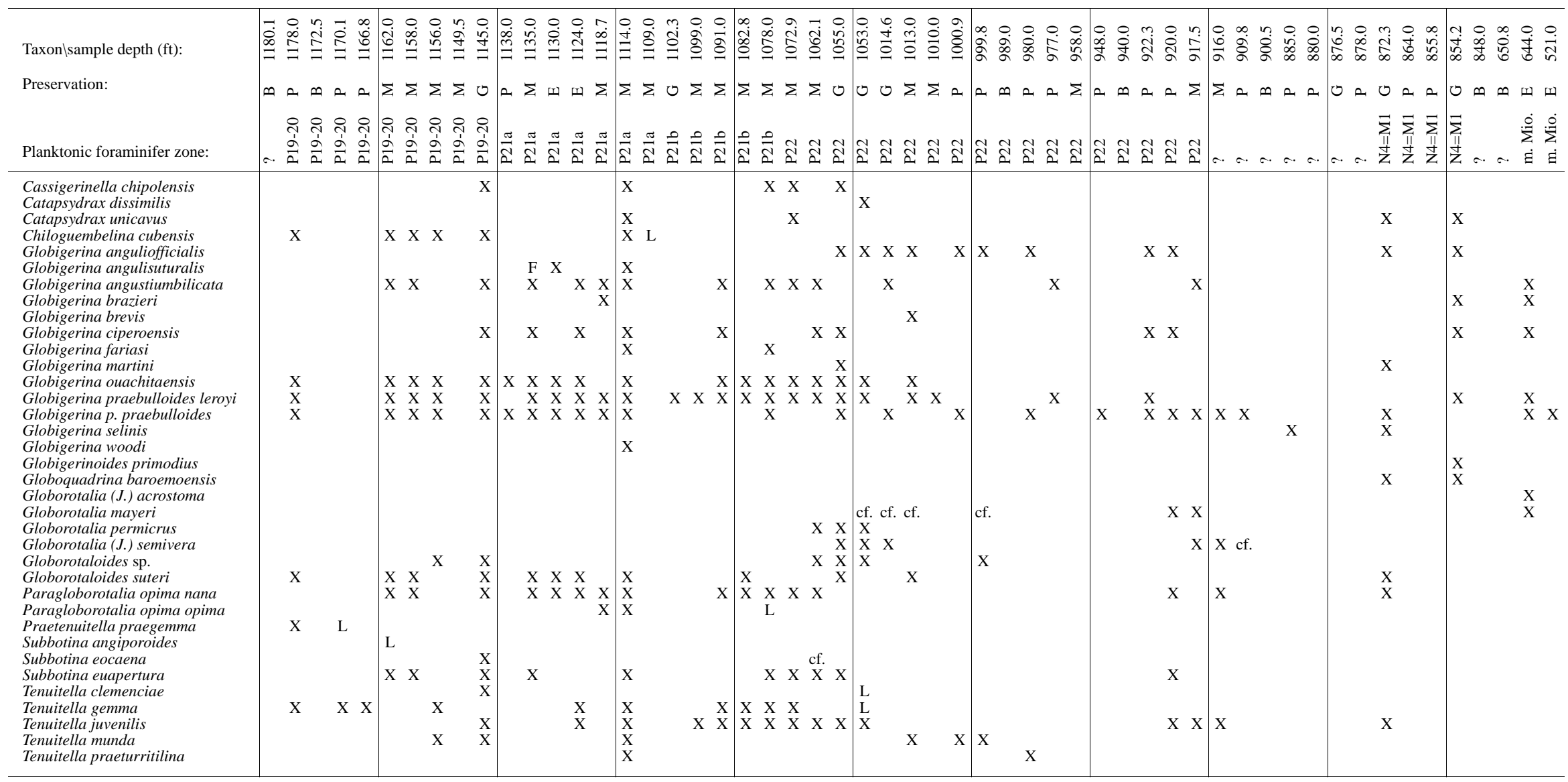

Note: See Table 1 for definitions. 
Chapter 18, this volume). Because of a more down-dip location, the upper Eocene is the most fossiliferous among the three borehole sections, and a more reliable biostratigraphy is possible. The interval from the base of the core to $1473 \mathrm{ft}(449.1 \mathrm{~m})$ does not contain any marker species that allow separation of Zones P15 and P16. The highest occurrence of Turborotalia pomeroli at $1451 \mathrm{ft}(442.4 \mathrm{~m})$ and the LO of T. cunialensis at $1473 \mathrm{ft}(449.1 \mathrm{~m})$ indicate that this interval is equivalent to lower Zone P16. The highest occurrence of Globigerapsis index at $1392 \mathrm{ft}$ (424.4 m) suggests an upper Zone P16 correlation for this sample. Although still not fully developed, Zone P17 is the thickest among all three boreholes. It extends from an unconformity at $1385-1360 \mathrm{ft}$ (422.3-414.6 m), where another unconformity separates the upper Eocene from the lower Oligocene Zone P18 (Fig. 4). A total of 38 taxa are recognized from the recovered upper part of the upper Eocene (Table 5).

\section{Oligocene}

\section{Lower Oligocene (Sewell Point Formation)}

The lower Oligocene in the Cape May borehole is $90 \mathrm{ft}$ thick (27.4 $\mathrm{m} ; 1360-1270 \mathrm{ft}$ [414.6-387.2 m]) based on planktonic foraminiferal biostratigraphy. The four samples $(1354.3,1353.7,1352.0$, and 1351 $\mathrm{ft}[412.9,412.7,412.2$, and $411.9 \mathrm{~m}])$ above the unrecovered interval (1360-1354.5 ft [414.6-413.0 m]) all contain a well-preserved Zone P18 assemblage characterized by the common occurrence of Pseudohastigerina micra. The HO of Turborotalia ampliapertura (used as the top of Zone P19) is at $1275 \mathrm{ft}(388.7 \mathrm{~m})$, above a barren interval between 1294 and $1276 \mathrm{ft}(394.5$ and $389.0 \mathrm{~m})$. Only one specimen of this taxon was observed. Planktonic foraminiferal biostratigraphy places the 1350 - to $1275.9-\mathrm{ft}$ interval $(411.6-388.7 \mathrm{~m})$ in Zone P19. The observed highest occurrence of Subbotina angiporoides is at $1271.9 \mathrm{ft}(387.8 \mathrm{~m})$, indicating a thin Zone P20 equivalent between $1275 \mathrm{ft}(388.7 \mathrm{~m})$ and a major disconformity at $1270 \mathrm{ft}$ (387.2 m). However, both Sr-isotope (Pekar et al., Chapter 15, this volume) and dinocyst data (de Verteuil, Chapter 11, this volume) indicate that strata between 1304 and $1270 \mathrm{ft}$ (397.6 and $387.2 \mathrm{~m}$ ) are upper Oligocene. This inconsistency remains unsolved. Preservation of microfossils is poor in this interval because of recrystallization and dissolution. The disconformity at $1270 \mathrm{ft}(387.2 \mathrm{~m})$ separates Zone P20 from the upper Oligocene Zone P21b (Fig. 4; Table 5). Zone $\mathrm{P} 21 \mathrm{a}$ is missing.

\section{Upper Oligocene (Atlantic City Formation)}

The upper Oligocene in the Cape May borehole is also $\sim 90 \mathrm{ft}$ thick $(27.4 \mathrm{~m} ; 1270-1180 \mathrm{ft}$ [387.2-359.8 m]) based on planktonic foraminiferal biostratigraphy. The Oligocene/Miocene boundary cannot be unequivocally recognized due to a lack of marker species. Stratigraphic correlation and $\mathrm{Sr}$-isotopic age estimates both place the boundary at $1180 \mathrm{ft}(359.8 \mathrm{~m})$.

The highest occurrence of Paragloborotalia opima opima at $1249.7 \mathrm{ft}(381.0 \mathrm{~m})$ separates the upper Oligocene into Subzone P21b and Zone P22. Preservation of microfossils is excellent in Subzone $\mathrm{P} 21 \mathrm{~b}$ except near disconformities at the top and bottom. In well-preserved intervals, Globigerinoides primordius and Globorotalia pseudokugleri occur. The lowest occurrence of Globorotalia pseudokugleri in basal Subzone P21b (1261.9 ft [384.7 m]) is unexpected, because this event occurs in middle Biozone P22 in deep-sea sections (Berggren et al., 1995). It may be that the Cape May specimens are precursors of well-developed representatives of the taxon.

Late Oligocene planktonic foraminiferal diversity is relatively low. Most samples have only 6-8 taxa of globigerinids and tenuitellids, although a total of 16 species are identified (Table 5). This low diversity is caused by deposition in a middle-inner neritic paleoenvironment and the oligotrophic nature of the late Oligocene ocean. The Zone P22 assemblage is similar to that of Subzone P21b, except that
Globigerinoides has its LO at $1222.7 \mathrm{ft}(372.8 \mathrm{~m})$. Preservation is poor in the lower part, good in middle and moderate toward the top.

\section{Miocene}

Lower Miocene (Kirkwood Formation 0, 1a, 1b, 1c and 2a)

The thickest lower Miocene (1180-615 ft [359.8-187.5 m]) sediments were penetrated at Cape May. The lower part (KW0) consists of predominantly glauconitic quartz sands between 1180 and $1062 \mathrm{ft}$ (359.8 and $323.8 \mathrm{~m}$ ). Planktonic foraminiferal assemblages have low diversity and poor to moderate preservation (Table 6).

The middle part of the lower Miocene (850-1062 ft [259.1-323.8 $\mathrm{m}]$ ) is a complete megasequence broken into several sequences (Kw la, 1b, 1c). The middle shelf clay from 1062 to $917 \mathrm{ft}(359.8-$ $279.6 \mathrm{~m}$; Kw la) is an coarsening-upward sequence. Its lower part (1062-967 ft [359.8-294.8 m]) contains well-preserved, relatively high diversity (26 species identified) planktonic foraminiferal assemblages (Table 6). The presence of Globigerina angulisuturalis suggests an early Miocene age (Zone M1 of Berggren et al., 1995, and N5 of Kennett and Srinivasan, 1983). This interval is equivalent to the $888-818 \mathrm{ft}(270.7-249.1 \mathrm{~m})$ clay at Atlantic City and represents the deepest water sedimentation in the Miocene. A middle neritic paleoenvironment is inferred.

The upper part of the lower Miocene is alternating sands and silty clays with sporadic microfossils. Small long-ranging taxa of Globigerina and Tenuitella predominate. The middle (Kw1c) is represented by a hiatus at Atlantic City. The Kw $2 \mathrm{a}$ unit is significantly thinner at Cape May $(95 \mathrm{ft}, 615-710 \mathrm{ft}[29.0 \mathrm{~m}, 187.5-216.5 \mathrm{~m}])$ than at Atlantic City (154 ft, 512-666 ft [47.0 m, 156.1-203.0 m]).

The lowest occurrence of Globoconella praescitula at $678 \mathrm{ft}$ (206.7 m) indicates that Kw2a (710-615 ft [216.5-187.5 m]) is upper lower Miocene Zone M3 (Berggren et al., 1995) or Zone N6 (Kennett and Srinivasan, 1983). Otherwise, planktonic foraminiferal biostratigraphy suffers from absence of marker species and rare occurrence of other taxa. Strontium isotopes provide the most precise chronologic control for the lower Miocene.

\section{Middle Miocene (Kirkwood 2b, 2c, 3 and Kirkwood-Cohansey? Formations)}

The lower part of the middle Miocene at Cape May correlates well with the Atlantic City borehole except that the 576- to 503-ft sands (175.6-153.4 m) dated as $\sim 13-14 \mathrm{Ma}$ using Sr-isotopes are not present at Atlantic City. Below the 576-ft disconformity (175.6 m), the silty clay contains few fossils. A low diversity planktonic foraminiferal assemblage in more clayey sediments is observed from the $\mathrm{Kw} 3$ sequence (503-432 ft [153.4-131.7 m]) in contrast to the barren equivalent (470-390 ft [143.3-118.9 m]) at Atlantic City. These differences in lithofacies as well as in planktonic foraminiferal appearance result from changing paleoenvironment: the Cape May Site was more oceanic than the Atlantic City Site in the late middle Miocene, although both were inner shelf to marginal marine in nature.

As in other sections, the sediments younger than middle Miocene are unfossiliferous, and planktonic foraminiferal biostratigraphy cannot be applied to those sediments.

\section{DISCUSSION}

The three boreholes drilled at Island Beach, Atlantic City and Cape May were designed to penetrate Cenozoic sediments deposited in different paleoenvironmental settings to evaluate the timing and magnitude of sea-level change on this passive continental margin (Miller, Chapter 1, this volume). A comparison of variations in sedimentary paleoenvironments among the three sites will provide information for fulfilling this purpose. 
Table 5. Eocene planktonic foraminifer ranges in the Cape May borehole section.

Taxonlsample depth (ft):

Preservation:

Planktonic foraminifer zone:

Cassigerinella winniana

Catapsydrax unicavus
Chiloguembelina cubensis

Chiloguembelina victoriana

Globigerapsis index

Globigerina anguliofficialis

Globigerina angustiumbilicata
Globigerina ciperoensis

Globigerina ciperoensis
Globigerina(?) danvillensis

Globigerina(?) danvill
Globigerina martini

Globigerina martini ouachitaensis

Globigerina praebulloides s.1.

Globigerinatheka mexicana

Globigerinita uvula

Globigerinoides primodius

Globorotalia (J.) increbescens

Globorotalia pendokugleri

Globorotaloides sp.

Globorotaloides suter

Hantkenina primitiva

Paragloborotalia opima nana

Paragloborotalia opima opim

Praetenuitella praegemma

Subbotina angiporoides

Subbotina corpulenta

Subbotina cryptomphala

Subbotina eocaena

Subbotina euapertura

Subbotina linaperta
Subbotina pseudovenezuelana

Subbotina pseudovenez
Subbotina tapuriensis

Tenuitella clemenciae

Tenuitella gemma

Tenuitella juvenilis

Tenuitella munda

Turborotalia ampliapertura

Turborotalia cerroazulensis

Turborotalia cunialensis

Turborotalia possagnoensis

Turborotalia pomeroli

Turborotalia praeturritilina

Turborotalia pseudoampliapertu

Te:

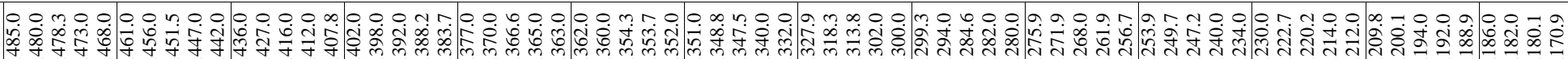

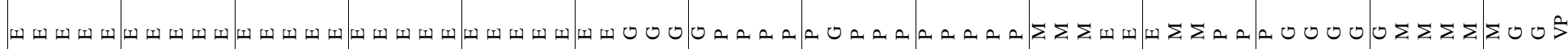

606

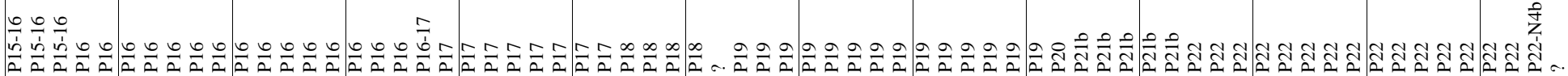

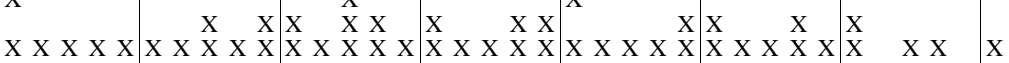

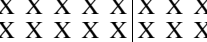

$\begin{array}{lllllllllllll} & x & X & X & X & X & x\end{array}$

$\mathrm{X}$

$X$ L

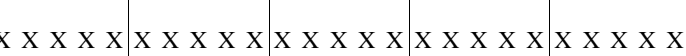

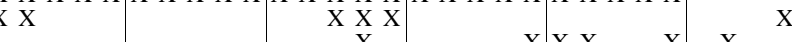

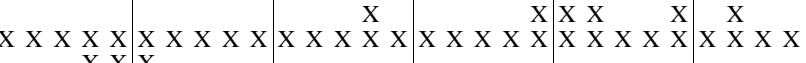

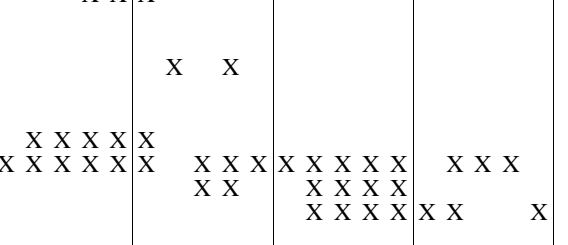

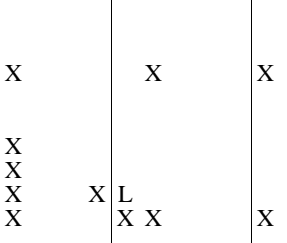

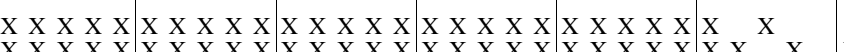

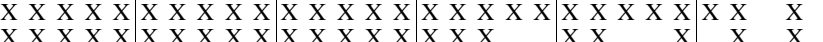

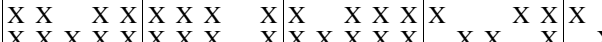

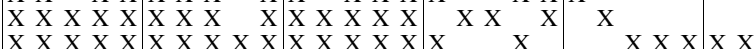

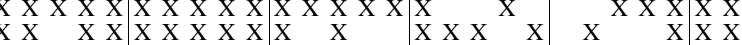

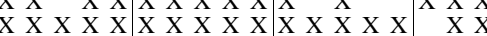

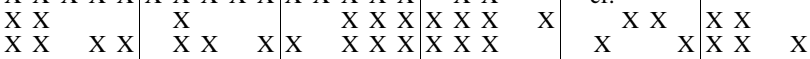

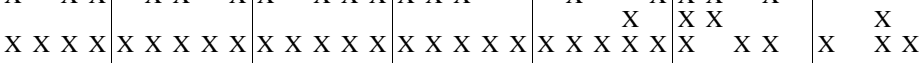

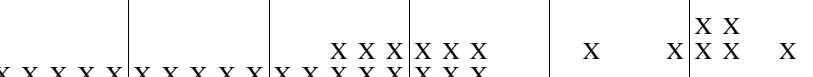

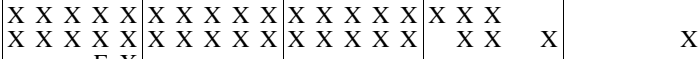

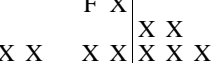

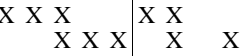

X X X x

\section{L}

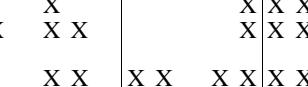

$\mathrm{X}$ X X

\begin{tabular}{l|ll}
$\mathrm{X}$ & $\mathrm{X}$ & $\mathrm{X}$ \\
$\mathrm{X}$ & $\mathrm{X}$ & $\mathrm{X}$
\end{tabular}

$x$

X X X X

$\mathrm{x}$

$\mathrm{X}$

$\mathrm{X}$

$\mathrm{X} X$

$\mathrm{X}$

\begin{tabular}{l|ll}
$\mathrm{X}$ & $\mathrm{X}$ & $\mathrm{X}$ \\
$\mathrm{F}$ & $\mathrm{X}$ & $\mathrm{X}$
\end{tabular}

\begin{tabular}{r|rrr}
$\mathrm{X}$ & $\mathrm{X}$ & $\mathrm{X}$ \\
$\mathrm{X}$ & $\mathrm{x}$ & $\mathrm{X}$ & $\mathrm{x}$ \\
$\mathrm{x}$ & $\mathrm{x}$ & $\mathrm{x}$ & $\mathrm{x}$
\end{tabular}

\begin{tabular}{ll|lll}
$\mathrm{X}$ & $\mathrm{X}$ & $\mathrm{X}$ & $\mathrm{X}$ \\
$\mathrm{X}$ & $\mathrm{X}$ & $\mathrm{X}$ & $\mathrm{X}$
\end{tabular}

$x$

$\mathrm{X} X \mathrm{X} \mathrm{X}$

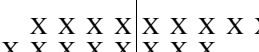

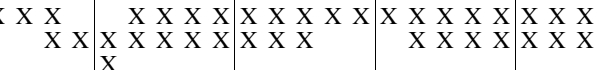

\begin{tabular}{l|llll} 
X X X X & X X X X X & X X & X \\
X
\end{tabular}

$\mathrm{X}$

\begin{tabular}{l|ll}
$\mathrm{X}$ & $\mathrm{X}$ \\
$\mathrm{X}$ & $\mathrm{X}$
\end{tabular}

$\mathrm{X}$
$\mathrm{X}$

$\mathrm{x}$

$\begin{array}{llll}X & X & X & X \\ X & L & \end{array}$
X X X X X X X X

$\mathrm{X} \mathrm{X}$

X L

$\mathrm{x}$ x X X $\mathrm{x}$ x

\begin{tabular}{llll|lll}
$X$ & $X$ & $X$ & $X$ & $X$ & $X$ & $X$ \\
$X$ & $X$ & $X$ & $X$ & $X$ & $X$ & $X$
\end{tabular}

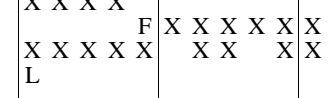




\section{Upper Cretaceous}

The $\sim 35 \mathrm{ft}(10.7 \mathrm{~m})$ of Upper Cretaceous bioturbated silty clay and clayey glauconite sands penetrated at Island Beach are similar to outcrop sections in the New Jersey Coastal Plain (Owens and Sohl, 1969; Olsson and Wise, 1987a, 1987b; Owens et al., Chapter 2, this volume). Glauconite represents sediment accumulation in middleouter shelf environments. Planktonic foraminiferal assemblages in the glauconitic sediments are characterized by small taxa and lack of large tropical/subtropical open-marine forms (e.g., Rosita, Planoglobulina, Racemiguembelina, and Ventilabrella). Both lithologic and biologic parameters point to stable middle-outer shelf sedimentation.

\section{The Cretaceous/Tertiary Boundary}

Unfortunately, the K/T boundary falls within an unrecovered interval between 1184.25 and $1188 \mathrm{ft}$ (361.1 and $362.2 \mathrm{~m}$ ). This unrecovered interval displays a distinct gamma-ray log peak. This elevated gamma-ray value may result from high concentration of glauconite sand or a lithified (phosphatized?) layer that occurs at disconformities in drilled boreholes in New Jersey Coastal Plain (Owens et al., 1995). The continuity of the K/T boundary at Island Beach therefore cannot be evaluated based on the borehole data alone. However, the nature of the sedimentary regime during the K/ $\mathrm{T}$ transition can be inferred from New Jersey Coastal Plain exposures. In outcrop sections, the Hornerstown Formation straddles the $\mathrm{K} / \mathrm{T}$ boundary. There is no physical break suggesting a depositional hiatus across the K/T boundary (Olsson, 1991). However, from planktonic foraminiferal data alone, a depositional hiatus may be indicated because the basal Paleocene planktonic foraminiferal Zones $\mathrm{P} 0$ and $\mathrm{P} \alpha$ have not been identified in the New Jersey Coastal Plain. These two zones are very short in duration ( 30 and 270 k.y., Berggren et al., 1995), and their absence may be attributed to a depositional/erosional hiatus, a condensed section, or mixing of the sediments. Leaching out of calcareous microfossils is another possibility. A recent dinoflagellate biostratigraphic study on the K/T boundary section exposed at Compton Quarry near Perrineville, New Jersey shows that all K/T boundary dinoflagellate zones are present (D. Habib, pers. comm., 1994). Therefore, at least some of the K/T boundary sections in the New Jersey Coastal Plain may have a biostratigraphically continuous transition from the Maastrichtian to the basal Danian.

As in all other sections, a significant turnover of planktonic foraminiferal assemblages in the borehole section is obvious. Twenty-four of the 27 latest Maastrichtian species disappear at the $\mathrm{K} / \mathrm{T}$ boundary. This reflects the severity of the end-Maastrichtian catastrophe.

\section{Paleocene}

As in other subsurface sections in New Jersey, the lower Paleocene Hornerstown Formation equivalent is glauconitic silty clay, and the upper Paleocene contains glauconitic silts and clays that are equivalent to the Vincentown Formation. By comparing the outcrop sections with Deep Sea Drilling Project (DSDP) Site 605, Olsson and Wise (1987a, 1987b) recognized three Paleocene unconformities in the New Jersey Coastal Plain. Sediments representing upper Subzone $\mathrm{P} 1 \mathrm{c}$ through lower Zone P3 are usually missing in outcrop exposures. The significance of drilling at Island Beach is the recovery of sediments equivalent to these Paleocene planktonic foraminiferal zones. At Island Beach, only one hiatus is recognized between Subzone P1c and Zone P2. The hiatus is marked by shell beds, discoloration of glauconite sand, and poor preservation of microfossils, which might result from subaerial exposure. However, no terrestrial sediment was observed. This hiatus should be short in duration because planktonic foraminiferal biostratigraphy does not support a significant deposi- tional break. Benthic foraminiferal biofacies study (Liu et al., Chapter 19, this volume) also indicates a constant middle- to outer-shelf paleoenvironment across this contact. Nannofossils identify another hiatus by the absence of Zone NP7 associated with disconformity at $1148 \mathrm{ft}$ (350 m; Miller et al., 1994).

\section{Eocene}

The lower Eocene Manasquan Formation (212.5 ft thick [64.8 m]) at Island Beach has uniform outer-shelf silty clay in the lower part and clay in the upper part. The whole formation is fossiliferous. Planktonic foraminiferal assemblages displayed the highest diversity of all Leg 150X sections with the occurrence of many pelagic taxa. An outer-shelf paleoenvironment is inferred (Browning et al., Chapter 17, this volume). From other subsurface wells and boreholes, Olsson (1991) recognized three hiatuses within the lower part of planktonic foraminiferal Zone P6, P7-P8 and lower P9, respectively. The hiatus in lower Zone P6 is equivalent to the $1076 \mathrm{ft}(328.0 \mathrm{~m})$ hiatus in the uppermost Paleocene at Island Beach. The other two are not recognized in the borehole by using planktonic foraminiferal biostratigraphic study alone. However, integrated magnetobiostratigraphic and benthic foraminiferal biofacies studies indicate at least four hiatuses (Browning et al., Chapter 17, this volume) that correlate with the base of Zones P6a, P6b, P7, and P9.

The middle Eocene is represented by the Shark River Formation (lower and upper), which is $83 \mathrm{ft}(25.3 \mathrm{~m} ; 862-779 \mathrm{ft}$ [262.8-237.5 $\mathrm{m}])$ at Island Beach and at least $100 \mathrm{ft}(32.8 \mathrm{~m} ; 1452-1352 \mathrm{ft}$ [442.7$412.2 \mathrm{~m}]$ ) thick at Atlantic City. All planktonic foraminiferal zones or equivalents (P10 to lower P15) are present, although precise zonation is difficult because of the absence of marker taxa and presence of a mixed layer. Browning et al. (Chapter 17, this volume) recognize three Shark River sequences at Island Beach on the basis of biofacies and magnetobiostratigraphy (a fourth is recognized at the ACGS\#4 borehole drilled at Mays Landing, New Jersey): (1) at the base of the Shark River (associated with the disconformable Zone P9/P10 boundary); (2) within the lower Shark River (associated with the disconformity between Zone P10 and Zone P11); and (3) at the base of the upper Shark River (associated with the disconformable Zone P11/ P12 boundary).

All three boreholes penetrated all or part of the newly named upper Eocene Absecon Inlet Formation, which has a thin clay layer at the base and thick silty clay on top. At Island Beach, the major part of the Absecon Inlet Formation is a glauconitic sand with clays in the upper part. This lithofacies change results from difference in paleoenvironmental setting: middle shelf at Island Beach and outer shelf at Atlantic City and Cape May. Thickness of the upper Eocene section is $48 \mathrm{ft}(14.6 \mathrm{~m})$ at Island Beach, $169 \mathrm{ft}(51.5 \mathrm{~m})$ at Atlantic City, and more than $140 \mathrm{ft}(42.7 \mathrm{~m})$ at Cape May (coring terminated within the upper Eocene). In a coastal plain borehole drilled by the USGS at Mays Landing (ACGS\#4), it is $77 \mathrm{ft}$ thick (23.5 m; Owens et al., 1988). However, in up-dip sections, upper Eocene strata are usually missing (Olsson, 1991). The diversity of planktonic foraminiferal assemblages is lowest at Island Beach, but increases toward Atlantic City and Cape May. This down-dip progressive thickening of sediments and the increase in planktonic foraminiferal diversity are consistent with increasingly oceanic paleoenvironments.

\section{Oligocene}

Oligocene strata in New Jersey were not recognized until the 1980's (Olsson et al., 1980; Owens et al., 1988). Drilling at three onshore sites recovered thick and well-developed Oligocene sequences in New Jersey. Thickness of the Oligocene is $192 \mathrm{ft}$ (58.5 m; 697-505 $\mathrm{ft}$ [212.5-154.0 m]) at Island Beach, $267 \mathrm{ft}(81.4 \mathrm{~m} ; 1181-914 \mathrm{ft}$ [360.1-278.7 m] at Atlantic City, and $180 \mathrm{ft}(54.9 \mathrm{~m} ; 1360-1180 \mathrm{ft}$ [414.6-359.8 m]) at Cape May. From Island Beach through Atlantic 
Table 6. Oligocene-Miocene planktonic foraminifer ranges in the Cape May borehole section.

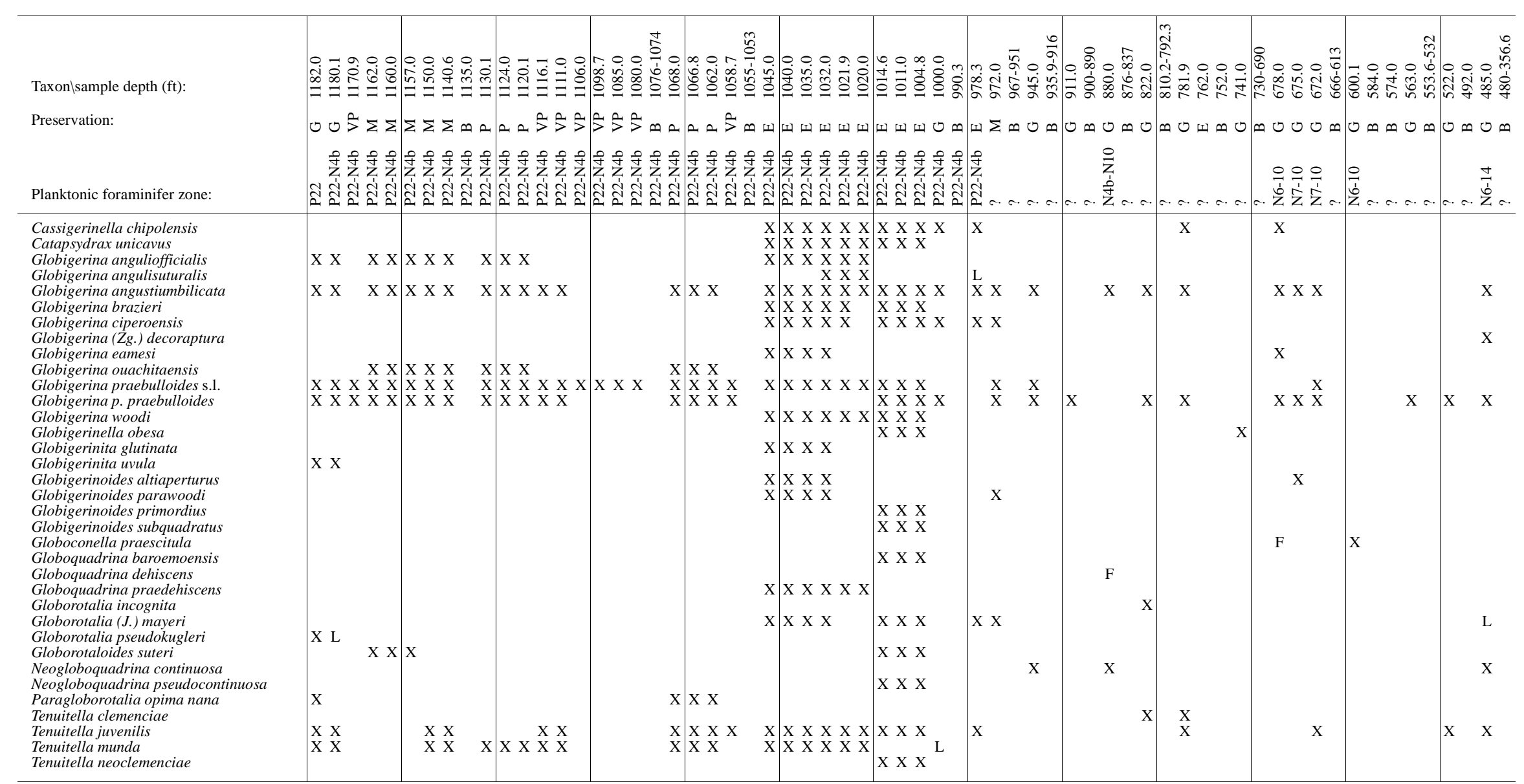

Note: See Table 1 for definitions. 
City to Cape May, the Oligocene becomes progressively more fossiliferous. However, the thickest and most complete section is in the Atlantic City borehole. Although precise separation is not possible, the stratigraphic equivalents of all Oligocene planktonic foraminiferal zones are recognized at Island Beach and Atlantic City. At Cape May, Zones P20-21a are not represented and the upper Oligocene (Zones P21b-22) is thinner than at Atlantic City. The Island Beach section has the lowest planktonic foraminiferal diversity and is mostly barren of upper Oligocene microfossils, indicating a shift of sedimentary setting from middle neritic to inner neritic. The Atlantic City and Cape May Oligocene sections show a similar regressive pattern upsection. Oligocene planktonic foraminiferal biostratigraphy in the three boreholes is less reliable than in the Eocene. In addition, Oligocene hiatuses have longer durations than those in the Eocene (Browning et al., Chapter 17, this volume; Pekar et al., Chapter 15, this volume). We attribute this to larger, more rapid glacioeustatic changes in the Oligocene.

\section{Miocene}

The Miocene planktonic foraminiferal assemblages and lithologies vary dramatically among the three borehole sections. At the updip Island Beach site, a few Miocene intervals contain estuarine benthic foraminiferal taxa and diatoms, but no planktonic foraminifers are observed. At Atlantic City, clayey lower Miocene sections and one interval of the middle Miocene contain low-diversity planktonic foraminiferal assemblages that provide approximate stratigraphic control. Small specimens of Tenuitella and Globigerina are major components of the assemblage. An inner to inner middle neritic or prodelta paleoenvironment can be inferred. At the down dip Cape May Site, the lower Miocene contains a relatively diverse assemblage because of the addition of Neogloboquadrina and Globorotalia, and a few intervals of the middle Miocene contain nondiagnostic taxa. In general, planktonic foraminifers and nannofossils provide little stratigraphic control in the Miocene onshore sections and age control relies on $\mathrm{Sr}$-isotopic stratigraphy supplemented by diatom biostratigraphy (Sugarman et al., 1993; Sugarman et al., Chapter 12, this volume; Miller et al., 1994b; Miller and Sugarman, 1995). However, the presence of these marine microfossils indicates a more oceanic (inner part of middle neritic) paleoenvironment at Cape May.

\section{CONCLUSIONS}

Planktonic foraminiferal biostratigraphic studies of the Leg 150X boreholes reveal planktonic foraminiferal assemblage replacements and changes in sedimentary regime in the latest Mesozoic and early to middle Cenozoic. During the Late Cretaceous-early Eocene, most planktonic foraminiferal zones are represented on the New Jersey Coastal Plain. Although deposition was punctuated by numerous hiatuses, the durations of the hiatuses are relatively short. This may reflect lower amplitude or slower rates of sea-level changes in the middle Eocene-Holocene. Biological factors were the primary control of the planktonic foraminiferal assemblages in the Cretaceous to middle Eocene. For example, the $\mathrm{K} / \mathrm{T}$ mass extinction event is so distinct that it eliminated the majority of planktonic foraminiferal species; the early Paleocene rapid global recovery following the K/T event is expressed in the coastal plain by increasing species diversity. Maximum planktonic foraminiferal diversity developed in the early-middle Eocene in the New Jersey Coastal Plain because of a more oceanic paleoenvironment resulting from high sea level. The late Eocene experienced a diversity drop, which was mainly caused by the middle/late Eocene extinction events that eliminated all species of Morozovella, Acarinina, Truncorotaloides, and Planorotalites. This event correlates with a global cooling (Miller, 1992). Planktonic foraminiferal diversity decreased significantly during the Eocene/Oli- gocene transition, again correlating with global cooling and ice-sheet development (Miller, 1992). Since the beginning of Oligocene, hiatuses have been more frequent and of longer duration. These, along with a significant increase in components of marginal marine sediments in the Oligocene, indicate larger, more rapid sea-level changes, consistent with larger changes in global ice volume. Latitudinal thermal gradients increased in the Oligocene-Miocene, and tropical/subtropical taxa were excluded from the now temperate New Jersey shelf.

\section{ACKNOWLEDGEMENTS}

This work benefited from the comments and suggestions by Dr. E.A. Mancini and Dr. B.T. Huber. Discussions with S. Pekar and P. Sugarman are appreciated. Supported by NSF Grants EAR92-18210. This is LDEO contribution number 5694.

\section{REFERENCES}

Berggren, W.A., Kent, D.V., Flynn, J.J., and van Couvering, J.A., 1985. Cenozoic geochronology. Geol. Soc. Am. Bull., 96:1407-1418.

Berggren, W.A., Kent, D.V., Swisher, C.C., III, and Aubry, M.-P., 1995. A revised Cenozoic geochronology and chronostratigraphy. In Berggren, W.A., Kent, D.V., Aubry, M.-P., and Hardenbol, J. (Eds.), Geochronology, Time Scales and Global Stratigraphic Correlation. Spec. Publ.Soc. Econ. Paleontol. Mineral., 54:129-212.

Berggren, W.A., and Miller, K.G., 1988. Paleogene tropical planktonic foraminiferal biostratigraphy and magnetobiochronology. Micropaleontology, 34:362-380.

Bolli, H.M., 1957. The genera Globigerina and Globorotalia in the Paleocene-lower Eocene Lizard Springs Formation of Trinidad, B.W.I. In Loeblich, A.R., Jr. (Ed.), Studies in Foraminifera. Bull.-U.S. Nat. Mus., 215:61-81.

Coccioni, R., Monaco, P., Monechi, S., Nocchi, M., and Parisi, G., 1988. Biostratigraphy of the Eocene-Oligocene boundary at Massignano (Ancona, Italy). In Premoli Silva, I., Coccioni, R., and Montanari, A. (Eds.), The Eocene-Oligocene Boundary in the Marche-Umbria Basin (Italy). Int. Subcomm. Paleogr. Strat., Eocene/Oligocene Meeting, Spec. Publ., II, 1:59-80.

Kennett, J.P., and Srinivasan, M.S., 1983. Neogene Planktonic Foraminifera: A Phylogenetic Atlas: Stroudsburg, PA (Hutchinson Ross).

Liu, C. and Olsson, R.K., 1992. Evolutionary radiation of microperforate planktonic foraminifera following the K/T mass extinction event. J. Foraminiferal Res., 22:328-346.

Loeblich, A.R., Jr., and Tappan, H., 1988. Foraminiferal Genera and Their Classification: New York (Van Nostrand Reinhold).

Miller, K.G., 1992. Middle Eocene to Oligocene stable isotopes, climate, and deep-water history: the Terminal Eocene Event? In Prothero, D., and Berggren, W.A. (Eds.), Eocene-Oligocene Climatic and Biotic Evolution: Princeton, NJ (Princeton Univ. Press), 160-177.

Miller, K.G., et al., 1996. Proc. ODP, Init. Repts., 150X (Suppl.): College Station, TX (Ocean Drilling Program).

Miller, K.G., Browning, J.V., Liu, C., Sugarman, P., Kent, D.V., Van Fossen, M., Queen, D., Goss, M., Gwynn, D., Mullikin, L., Feigenson, M.D., Aubry, M.-P., and Burckle, L.D., 1994a. Atlantic City site report. In Miller, K.G., et al., Proc. ODP, Init. Repts., 150X: College Station, TX (Ocean Drilling Program), 35-55.

Miller, K.G., Kent, D.V., Brower, A.N., Bybell, L.M., Feigenson, M.D., Olsson, R.K., and Poore, R.Z., 1990. Eocene-Oligocene sea-level changes on the New Jersey coastal plain linked to the deep-sea record. Geol. Soc. Am. Bull., 102:331-339.

Miller, K.G., and Sugarman, P.J., 1995. Correlating Miocene sequences in onshore New Jersey boreholes (ODP Leg 150X) with global $\delta^{18} \mathrm{O}$ and Maryland outcrops. Geology, 23:747-750.

Miller, K.G., Sugarman, P., Van Fossen, M., Liu, C., Browning, J.V., Queen, D., Aubry, M.-P., Burckle, L.D., Goss, M., and Bukry, D., 1994b. Island Beach site report. In Miller, K.G., et al., Proc. ODP, Init. Repts., 150X: College Station, TX (Ocean Drilling Program), 5-33.

Olsson, R.K., 1991. Cretaceous to Eocene sea-level fluctuations on the New Jersey margin. Sediment. Geol., 70:195-208. 
Olsson, R.K., Hemleben, C., Berggren, W.A., and Liu, C., 1992. Wall texture classification of planktonic Foraminifera Genera in the lower Danian. $J$. Foraminiferal Res., 22:195-213.

Olsson, R.K. and Liu, C., 1994, On the reality of the KT boundary. In: Developments Regarding the K/T Event and Other Catastrophes in Earth History. LPI Contribution No. 825, Lunar and Planetary Institute, Houston. P. 87-88.

Olsson, R.K., Miller, K.G., and Ungrady, T.E., 1980. Late Oligocene transgression of middle Atlantic coastal plain. Geology, 8:549-554.

Olsson, R.K., and Wise, S.W., 1987a. Upper Maestrichtian to middle Eocene stratigraphy of the New Jersey slope and coastal plain. In van Hinte, J.E., Wise, S.W., Jr., et al., Init. Repts. DSDP, 93 (Pt. 2): Washington (U.S. Govt. Printing Office), 1343-1365.

Olsson, R.K., and Wise, S.W., 1987b. Upper Paleocene to middle Eocene depositional sequences and hiatuses in the New Jersey Atlantic Margin. In Ross, C., and Haman, D. (Eds.), Timing and Depositional History of Eustatic Sequences: Constraints on Seismic Stratigraphy. Spec. Publ. Cushman Found. Foraminiferal Res., 24:99-112.

Owens, J.P., Bybell, L.M., Paulachok, G., Ager, T.A., Gonzalez, V.M., and Sugarman, P.J., 1988. Stratigraphy of the Tertiary sediments in a 945foot-deep core hole near Mays Landing in the southeastern New Jersey Coastal Plain. Geol. Surv. Prof. Pap. U.S., 1484.

Owens, J.P., and Sohl, N.F., 1969. Shelf and deltaic paleoenvironments in the Cretaceous-Tertiary formations of the New Jersey Coastal Plain. In Subitzky, S. (Ed.), Geology of Selected Areas in New Jersey and Eastern Pennsylvania and Guidebook of Excursions: New Brunswick, NJ (Rutgers Univ. Press), 235-278.

Owens, J.P., Sugarman, P.J., Sohl, N.F., Parker, R., Houghton, H.H., Volkert, R.V., Drake, A.A., and Orndorff, R.C., 1995. Geologic map of New Jersey: Central Sheet. Open-File Rep.-U.S. Geol. Surv., 95-253.
Poag, C.W., and Aubry, M.-P., 1995. Upper Eocene impactites of the U.S. coast: depositional origins, biostratigraphic framework, and correlation. Palaios, 10:16-43.

Poore, R.Z., and Bybell, L.M., 1988. Eocene to Miocene biostratigraphy of New Jersey core ACGS \#4: Implications for regional stratigraphy. Geol. Surv. Prof. Pap. U.S., 1829.

Signor, P.W., III, and Lipps, J.H., 1982. Sampling bias, gradual extinction patterns, and catastrophes in the fossil record, Spec. Pap. Geol. Soc. Am., 190:291-296.

Snyder, S.W., Miller, K.G., and Saperson, E., 1996. Paleogene and Neogene planktonic foraminiferal biostratigraphy of the New Jersey continental slope: Sites 902, 903, and 904 (Leg 150). In Mountain, G.S., Miller, K.G., Blum, P., Poag, C.W., and Twichell, D.C. (Eds.), Proc. ODP, Sci. Results, 150: College Station, TX (Ocean Drilling Program), 3-15.

Speijer, R.P., and Samir, A.M., (1997). Globanomalina luxorensis, a Tehyan biostratigraphic marker of latest Paleocene global events. Micropaleontology. 43:51-62.

Sugarman, P.J., Miller, K.G., Owens, J.P., and Feigenson, M.D., 1993. Strontium isotope and sequence stratigraphy of the Miocene Kirkwood Formation, Southern New Jersey. Geol. Soc. Am. Bull., 105:423-436.

Date of initial receipt: 1 February 1996

Date of acceptance: 23 September 1996

Ms 150XSR-308 